\title{
Bekerja Jarak Jauh (Telecommuting): Konsep, Penerapan dan Pembelajaran
}

\author{
Oswar Mungkasa ${ }^{1}$ \\ Kementerian Perencanaan Pembangunan Nasional/Bappenas - Indonesia
}

\begin{abstract}
Abstraksi
Bekerja jarak jauh atau bekerja tidak harus di kantor menjadi solusi ketika suatu pekerjaan tidak memungkinkan untuk dilakukan di tempat kerja. Bekerja jarak jauh juga dimaksudkan untuk memberikan keleluasaan bagi pegawai dalam menyelesaikan pekerjaannya dimana saja dan kapan saja, dengan pemanfaatan teknologi komunikasi dan informasi modern. Bagi instansi/perusahaan produktifitas dan efisiensi operasional menjadi pendorong untuk menerapkan keleluasaan kerja (flexible work). Kerja leluasa mempunyai peluang menguntungkan bagi pegawai dan juga organisasi melalui dukungan perilaku kerja positif seperti komitmen, motivasi dan kepuasan kerja, dan berkinerja baik. Namun demikian, kerja jarak jauh atau kerja leluasa belum sepenuhnya dapat diterima. Kebutuhan pegawai untuk bersosialisasi, bertukar data menjadi kendala sehingga dapat mengurangi produktifitasnya. Work From Home (WFH) sebagai pelaksanaan bekerja jarak jauh dan tidak harus di kantor sebaiknya hanya pada waktu tertentu saja, tidak dilakukan dalam jangka waktu lama atau bahkan menjadi regular, yaitu ketika membutuhkan perubahan suasana, kondisi darurat atau adanya kebutuhan tertentu yang mengharuskan berada di rumah. Selain itu, dibutuhkan persyaratan minimum yang sebaiknya terpenuhi sebagai pendukung agar work from home menjadi berkualitas.
\end{abstract}

Kata Kunci: Bekerja jarak jauh, kerja leluasa, flexible work, bekerja dari rumah, work from home (wfh)

\footnotetext{
1 Oswar Mungkasa adalah Fungsional Perencana Madya di Kementerian Perencanaan Pembangunan Nasional/Bappenas Republik Indoneisa. E-mail: oswar.mungkasa63@gmail.com
} 


\section{Bekerja Jarak Jauh (Telecommuting): Konsep, Penerapan dan Pembelajaran}

Oswar Mungkasa

\section{A. Definisi dan Karakter Bekerja Jarak Jauh (telecommuting)}

Pernyataan seperti bekerja 25 jam sehari, tidak cukup waktu, atau bekerja 24 jam sehari 7 hari seminggu telah menjadi keluhan umum. Perasaan tidak cukup waktu ini menjadikan para peneliti kemudian berfokus pada topik pengaturan waktu kerja alternatif (alternative work arrangement) seperti flexitime, telecommuting dan praktek keseimbangan bekerja-berkehidupan (work-life balance) dalam satu dekade terakhir (Jackson dan Fransman, 2018). Istilahnya sendiri dalam bahasa Inggris beragam mulai dari yang sering dipakai seperti telecommuting, flexy work, flexibility working, sampai telework. Bekerja jarak jauh juga mengandung pengertian bekerja fleksibel/leluasa, yang artinya jam kerja disesuaikan dengan kondisi yang ada.

Definisi bekerja jarak jauh berkembang seiring waktu. Awalnya istilah yang dipergunakan adalah 'electronic homework' yang terdegar kuno sekarang. Istilahnya berkembang menjadi 'telecommuting', menggunakan konsep Jack Nilles pada tahun 1973 (Nilles dkk. 1976). Kemudian 'flexiwork', sebuah istilah yang lebih dikenal di Eropa.

Penamaan yang beragam terhadap bekerja jarak jauh dapat ditemukan pada berbagai tulisan diantaranya, mulai dari 'remote working', 'distance working' (Holti dan Stern 1986) atau 'outwork' (Probert dan Wajcman 1988). Lainnya mengategorikannya berdasar beragam bentuk bekerja jarak jauh seperti 'homework', 'alternative officing' dan 'mobile working' (Gordon 1996). Selain itu, perbedaan juga dibuat antara bekerja dari rumah dengan kantor pusat, gabungan bekerja pada kantor pusat dan kantor cabang, dan nomaden tanpa kantor (Stanworth dan Stanworth, 1991). Pendekatan lebih analitik seperti Brandt (1983) dan Holti dan Stern (1986), telah mengategorikan berdasar pertimbangan keruangan, dan perangkat koordinasi (Jackson dan Wielen ed., 1998)

Pengertian bekerja jarak jauh adalah pekerjaan dilakukan oleh seseorang (pegawai, pekerja mandiri, pekerja rumahan) secara khusus, atau hanya waktu tertentu, pada sebuah lokasi jauh dari kantor, menggunakan media telekomunikasi sebagai alat kerja (Huuhtanen, 1997). Menurut Konradt, Schmook, dan Malecke (2000), bekerja jarak jauh dimaksudkan sebagai cara bekerja dalam sebuah organisasi yang dilaksanakan sebagian atau seluruhnya di luar kantor konvensional dengan bantuan layanan telekomunikasi dan informasi (DeRossette, 2016).

Definisi bekerja jarak jauh atau telecommuting telah banyak berubah sejak ditemukan 40 tahun lalu. Hasil pengamatan sekilas menunjukkan bahwa definisi bekerja jarak jauh setidaknya menyangkut 4 (empat) hal yaitu

(i) pilihan tempat kerja, yang mengacu pada penghematan waktu/jarak fisik (tele);

(ii) sebagian atau substitusi total dari penglaju (commute) harian;

(iii) intensitas aktifitas bekerja jarak jauh;

(iv) ketersediaan teknologi komunikasi dan informasi. Nilles, yang dikenal sebagai bapak bekerja jarak jauh, mendefinisikan sebagai fenomena pekerja yang dapat menjangkau informasi di tempat kerja memanfaatkan teknologi tanpa kehadiran secara langsung (Nilles, 1994).

Beberapa peneliti seperti Crimando and Godley (1985); De Marco (1995); Handy dan Mokhtarian (1995) mendefinisikan lebih rinci dengan menekankan pemanfaatan peralatan elektronik seperti komputer, telepon seluler, email dan jasa basis data dalam jaringan (Asgari, 2015). 
Terdapat 2 (dua) tipe bekerja jarak jauh yaitu bekerja dari rumah (home-based telecommuting) dan bekerja dari kantor cabang (center-based telecommuting). Seperti namanya, bekerja dari rumah menunjukkan lokasi kerja di rumah dengan berkomunikasi ke kantor, sementara bekerja dari kantor cabang/satelit menunjukkan lokasi bekerja bukan di rumah tapi di kantor yang terdekat dari rumah. Menggunakan perspektif transportasi, bekerja dari rumah mengurangi sepenuhnya perjalanan penglaju, sementara bekerja dari kantor cabang hanya mengurangi jarak perjalanan (Asgari, 2015).

Teo dkk. (1998) menggambarkan bekerja jarak jauh sebagai menyelesaikan tugas jauh dari lokasi kantor regular setidaknya satu sampai dua hari per minggu. Perlu juga diingat bahwa bekerja jarak jauh tidak perlu melibatkan bekerja di rumah, tetapi bisa juga termasuk memanfaatkan pusat bekerja jarak jauh (telework center), berlokasi di luar rumah dan kantor regular. Penelitian tahun 2001, The International Telework Association and Council ITAC-2, menemukan bahwa bekerja jarak jauh dapat dilakukan di rumah, jalan, lokasi pelanggan, atau kantor satelit. Sebagai tambahan, beragam penelitian menyepakati bahwa bekerja jarak jauh mengarah pada substitusi sebagian atau seluruhnya dari penglaju harian (Nilles, 1988; Mokhtarian, 1991; Sampath dkk., 1991; Handy dan Mokhtarian, 1995; Walls dan Safirova, 2004)

Bekerja jarak jauh mengalahkan konsep subordinasi, ketika bekerja berdasar perintah dan kendali langsung pemberi kerja. Pemikiran baru dibutuhkan di kalangan pemberi kerja dan pegawai, bahwa kendali dan pengawasan tidak didasari kehadiran tetapi kualitas kerja. Bekerja berbeda waktu dan tempat membutuhkan saling percaya satu sama lain. Menjadi penting mencapai keseimbangan antara privasi pekerja jarak jauh dan keterhubungan dengan tempat kerja yang kadang di rumah. Keberhasilan menggabungkan bekerja dan kehidupan pribadi membutuhkan pemisahan ruang kerja dan jaminan tidak terganggunya konsentrasi kerja, termasuk isu privasi dan perlindungan data. Resiko bersinggungan dengan pihak luar juga penting diperhatikan (Korte, 1996).

Menurut Heathfield (2019) terdapat beragam skema bekerja diantaranya bekerja leluasa (flexible schedule), dan bekerja jarak jauh (telecommuting), tentu saja selain bekerja penuh sampai bekerja sementara. Sementara bekerja leluasa dimaknai sebagai pekerja dimungkinkan bekerja berbeda dari waktu kerja konvensional sehingga pekerja dapat menyeimbangkan bekerja dan berkehidupan. Bekerja jarak jauh (dari rumah dan/atau lokasi lain di luar kantor) adalah pengaturan bekerja leluasa yang memungkinkan bekerja jauh dari kantor sepanjang atau sebagian waktu. Beberapa perusahaan memungkinkan bekerja jarak jauh secara rutin tetapi sebagian hanya memungkinkan pada saat tertentu saja sesuai kebutuhan.

Fleksibilitas diartikan oleh Costa, Sartori and Akerstedt (2006) sebagai tingkatan kemandirian dan pengambilan keputusan individu. Literatur mengategorikan praktek kerja fleksibel (flexible work) sebagai praktek kerja kantoran (office-based) dan lokasi leluasa (flexiplace) (Grobler dan De Bruyn, 2011); atau waktu leluasa (flexitime) dan lokasi leluasa (flexiplace) (Munsch, Ridgeway dan Williams, 2014). Kelly, Moen dan Tranby (2011) mengacu pada fleksibilitas terhadap kendali jadwal, sebab pilihan kerja fleksibel dapat mencakup kerja darurat (contingent work), kerja kontrak (contract work) dan pegawai sesaat (just-in-time staffing). Waktu kerja leluasa membutuhkan dukungan budaya organisasi (Galea, Houkes and De Rijk 2014), dan perlu dipahami juga bahwa pimpinan perlu menyadari jika staf melalui beragam tahapan sepanjang karirnya dan kebutuhan khususnya dapat berubah (Fransman 2015). Hasilnya menunjukkan bahwa kerja fleksibel seperti lokasi leluasa (flexiplace/telework) dan waktu leluasa (flexitime), berdampak baik pada keseimbangan kerjaberkehidupan (Hill et al. 2001).

Keleluasaan waktu kerja (Flexible Working Time) atau waktu kerja leluasa (Flexi Time) adalah sistem pengaturan kerja yang memberi lebih banyak kebebasan kepada 
karyawan dalam mengatur jam kerja mereka. Flexi Time banyak digunakan oleh perusahaanperusahaan berskala global yang sulit jika harus menyamakan waktu bekerja karena adanya perbedaan zona waktu di beberapa negara. Flexi Time memegang prinsip bahwa jam berapapun karyawan masuk, asalkan pekerjaan selesai dan waktu yang digunakan memenuhi jumlah jam yang sudah disepakati dalam perjanjian kerja. Di bawah ini adalah beberapa jenis Flexi Time yang sering digunakan:

\section{a. Fixed Working Hours}

Sistem kerja yang memungkinkan pegawai dapat bebas memilih sesi kerjanya setiap hari sesuai ketetapan perusahaan sepanjang memenuhi jumlah minimal 40 jam seminggu. Sebagai contoh, perusahaan memberi kebebasan kepada karyawan untuk memilih jam kerja dengan ketentuan 25\% karyawan bekerja pada jam 07.00-15.00; 25\% karyawan bekerja pada jam 08.00-16.00; 25\% karyawan bekerja pada jam 09.0017.00; dan 25\% terakhir dari karyawan bekerja pada jam 10.00-18.00.

\section{b. Flexible Working Hours}

Sistem kerja yang memungkinkan pegawai bekerja leluasa sepanjang memenuhi jumlah waktu minimal adalah 40 jam per minggu. Jumlah jam kerja tidak harus sama setiap harinya.

\section{c. Variable Working Hours}

Sistem kerja yang mengharuskan pegawai hadir pada jam tertentu di kantor dan pegawai dapat menetapkan sendiri waktu selebihnya. Sebagai contoh, karyawan diwajibkan masuk setiap hari jam 09.00-13.00, dan selebihnya dapat bekerja jarak jauh sampai memenuhi minimal 40 jam seminggu (Ayuna, 2019)

Penelitian lain menyimpulkan terdapat 3 (tiga) kategori bekerja leluasa (flexible work arrangement/FWA) yaitu flexi-time (leluasa jadwal), tele-homeworking (leluasa tempat), dan part-time (leluasa lama bekerja). Dalam kenyataannya ketiganya dapat digabungkan dan saling melengkapi disesuaikan kebutuhan (Possenried dan Plantenga, 2011). Sehingga bekerja leluasa diartikan sebagai kemampuan pekerja mengendalikan sendiri lamanya bekerja, tempat bekerja jauh dari kantor, penjadwalan kerja yang ditawarkan perusahaan (Atkinson dan Hall, 2011).

Konsep kerja jarak jauh telah dijelaskan dengan beragam cara, tergantung penggunaannya dalam keseharian yang kurang lebih mencakup kerja leluasa (flexiwork), jarak dan jangkauan tempat kerja, kerja jarak jauh berpindah-pindah (mobile/nomadic telework). Terdapat setidaknya 3 (tiga) dimensi yang berlaku terhadap seluruh definisi yaitu tempat/lokasi, waktu/jadwal, dan pemanfaatan teknologi komunikasi dan informasi modern. Kerja jarak jauh dapat mencakup beragam suasana, mulai dari kerja jarak jauh di rumah sampai kerja jarak jauh berpindah, atau kerja jarak jauh pada lokasi terpencil (Korte, 1996).

\section{B. Sejarah Ringkas dan Perkembangan}

Istilah bekerja jarak jauh pertama kali muncul dalam buku The Human Use of Human Beings Cybernetics and Society oleh Norbert Wiener pada tahun 1950 yang menggunakan istilah telework (istilah yang popular di Eropa sampai saat ini) (Siddharta dan Malika, 2016). Sementara pada tahun 1974, istilah 'telecommute' dipergunakan pertama kali dalam laporan University of Southern California yang berfokus pada proyek pengurangan lalu lintas jam puncak yang dibiayai oleh the National Science Foundation (Nilles dkk, 1974). Pada tahun 1980, Alvin Toffler memperkenalkan ide bekerja jarak jauh (telework) dalam 3 (tiga) tahap berdasar munculnya "the third wave" (Siddhartha dan Malika, 2016).

Dimulai pada tahun 1970 sebagai jawaban upaya pengurangan penglaju (commuting) dan konsumsi energi, tahun 1980 bekerja jarak jauh bangkit kembali sebagai pengaturan bekerja leluasa (fleksibel), yang memungkinkan tercipta keseimbangan bekerja dan 
kehidupan keluarga, kekurangan tenaga terampil terpenuhi, dan ekonomi kawasan pinggiran terpadu dengan pusat kota (Kinsman 1987; Huws dkk. 1990). Pada tahun 1990an lebih banyak lagi perhatian terhadap isu desain tempat kerja, pengelolaan fasilitas dan kebutuhan mengelola waktu kerja dan ruang kerja untuk mendorong produktifitas dan efektifitas (Jackson, dan Wielen ed., 1998).

Di AS, diskusi bekerja jarak jauh lebih dulu dari Eropa, yang dimulai oleh Nabi bekerja jarak jauh' Jack Nilles pada tahun 1973. Analisis sistematik tentang pro dan kontra bekerja jarak jauh dipublikasikan pada tahun 1976 oleh Nilles dibantu oleh Carlson, Gray and Hanneman (Nilles $d k k$., 1976). Laporan tersebut menyangkut manfaat dan biaya ekonomi perjalanan ke dan dari kantor dibandingkan dengan biaya dan manfaat bekerja di rumah.

Secara umum, diskusi bekerja jarak jauh di AS terkait erat dengan penglaju dari rumah ke kantor berikut masalah kemacetannya. Akibatnya, istilahnya menjadi 'telecommuting'. Hal ini menyebabkan banyak pekerja jarak jauh yang menjadi tidak termasuk dalam definisi telework. Pertama, sebagian pekerja jarak jauh bekerja wiraswasta, bisnis rumahan, seperti konsultan yang mengirim laporan dari rumah. Pekerja ini bisa saja arsitek, bekerja paruh waktu di rumah, mengirim hasil karyanya via surat elektronik, kadang bepergian (commuting) mengawasi pekerjaan, atau pekerja bidang informatika. Kedua, sebagian pekerja jarak jauh memanfaatkan telekomunikasi dalam rangka menghindari perjalanan ke pelanggan, atau pelanggan mendapatkan hasil kerja melalui internet. Contohnya, berdiskusi melalui video internet, layanan sosial melalui internet, bahkan home shopping and home banking dapat masuk kategori ini. Ketiga, semakin majunya teknologi informatika dan ketersediaan komputer jinjing memungkinkan bekerja di mana saja seperti pewarta, yang mengirim laporan langsung dari lapangan. Meningkatnya keleluasaan, dan mendukung pemahaman positip, istilah resmi di Eropa menjadi 'flexiwork' (Jackson dan Wielen ed., 1998)

Sepanjang dekade 70 sampai 80, bekerja jarak jauh di Eropa masih dipandang sebelah mata. Pada waktu itu, 'telework' sering disebut dengan istilah 'electronic homework', bermakna pekerjaan kantor rendahan dari rumah, baik berdasar kontrak penuh waktu atau paruh waktu. Umumnya berkonotasi negatif. Pekerja jarak jauh dicontohkan sebagai ibu rumah tangga yang mempunyai anak, terpisah dari komunitas kantor, mengerjakan pekerjaan monoton bagi pemberi kerja. Literatur kritis menggunakan istilah 'electronic homework' sebagai ganti 'telework' untuk menekankan kondisi awal industri rumahan. Berdasar analisis kritis, wanita berpotensi menjadi pekerja jarak jauh (Jackson dan Wielen ed., 1998)

Konsep bekerja jarak jauh mulai mendapat perhatian banyak pihak pada akhir abad 20, menyertai kemunculan teknologi komunikasi dan komputer pribadi. Istilah telecommuting atau "telework" makin dikenal pada tahun 80-an ketika para pekerja diberi kesempatan untuk menyelesaikan tugas dari rumah dibandingkan dengan datang langsung ke kantor (Potter, 2003). Pada saat itu, penerapan pekerjaan secara telecommuting (bekerja jarak jauh) diberlakukan satu hari dalam seminggu (Siha dan Monroe, 2006). Pada dekade yang sama, program ujicoba bekerja jarak jauh diinisiasi di berbagai lokasi di Amerika Serikat dan pada tahun 1990-an banyak negara bagian, pemerintah daerah, dan perusahaan telah menerapkan bekerja jarak jauh. Didorong oleh perkembangan teknologi infiormasi dan persaingan bisnis internasional, lebih banyak lagi organisasi yang menerapkan bekerja jarak jauh (Asgari, 2015).

Penerapan bekerja jarak jauh terus mengalami perkembangan, pada tahun 1995 di Amerika saja terjadi peningkatan pekerja jarak jauh (telecommuter) dari 8,5\% menjadi $11 \%$ di tahun 1997 (Force, 2000). Bekerja jarak jauh mulai mendapat perhatian luas di Amerika Serikat sejak awal tahun 2000 dan berkembang cepat. Berdasar data Biro Pusat Statistik Amerika Serikat, jumlah pekerja jarak jauh di Amerika Serikat berkembang terus dari 18,7\% (2004) menjadi 23,3\% (2014) (Ohio,2015). 
Saat ini, pekerja jarak jauh di Amerika mencapai 3,2 juta pekerja. Alasan utamanya adalah bekerja lebih leluasa. Jika termasuk pekerja mandiri, pekerja non tradisional lapangan (misal konstruksi), perusahaan dengan seluruh pekerjanya bekerja jarak jauh, dan pekerja jarak jauh hanya 1 (satu) hari per minggu, maka jumlah pekerja jarak jauh akan menjadi sekitar 30 persen dari seluruh tenaga kerja Amerika Serikat. Sebuah penelitian menyatakan sekitar 80 persen penduduk Amerika berkeinginan bekerja jarak jauh setidaknya sebagian dari waktu kerjanya selama seminggu (Ohio, 2015).

Setelah tragedi penyerangan WTC dan Pentagon 11 September 2001, keinginan para pekerja untuk bekeja jarak jauh meningkat tajam. Sebagian besar alasan mereka adalah untuk menghindari ancaman/kecelakaan di tempat kerja, mengurangi kegelisahan saat kerja dan dapat menyelesaikan pekerjaan dengan lebih baik (Budhiekusuma, 2017).

Bekerja jarak jauh tidak hanya menarik bagi milineal tetapi juga pegawai senior. Umur rata-rata pekerja jarak jauh di Amerika Serikat sekitar 49 tahun, pendapatan rata-rata USD 58.000 per tahun, dan bekerja jarak jauh setidaknya 2 (dua) hari per bulan. Sementara, 9 (sembilan) persen pekerja melaporkan bekerja jarak jauh lebih dari 1/3 waktunya per bulan (Ohio, 2015).

\section{Manfaat, Kerugian dan Dampak}

Dipahami sepenuhnya bahwa manfaat dan kerugian maupun kelebihan dan kekurangan bekerja jarak jauh dan bekerja leluasa sangat beragam tergantung preferensi masing-masing baik pekerja, perusahaan, pemerintah bahkan masyarakat. Selain itu, karakter sosial-ekonomi termasuk faktor lokasi juga mempengaruhi pemahaman tentang manfaat dan kerugian ini. Sebagian manfaat dan kerugian telah disepakati dan menjadi pemahaman bersama, namun beberapa lainnya masih belum disepakati bahkan menjadi kontroversi.

Secara umum, Heathfield (2019) dalam bukunya menyimpulkan manfaat bekerja jarak jauh dan leluasa adalah

(i) Manfaat paling utama adalah keleluasaan bercengkerama dengan keluarga, mengurus kepentingan keluarga dan berkehidupan dengan lebih nyaman. Bekerja leluasa memungkinkan memilih waktu yang tepat untuk bekerja semisal ketika sedang merasa nyaman, dan segar

(ii) Bekerja leluasa juga memungkinkan memilih waktu yang tepat berada di kantor dan di luar kantor atau rumah. Dengan demikian, pekerja jarak jauh dapat menghindari kemacetan sehingga dapat mengurangi waktu perjalanan dan mengurangi tingkat stres. Selain itu, menghemat waktu dan mengurangi biaya perjalanan

(iii) Pekerja jarak jauh merasakan kenikmatan dapat mengatur sendiri jadwal dan lingkungan kerja sehingga terasa seperti wiraswasta. Selain itu, memudahkan mencegah bekerja terbebani (overload). Sementara keleluasaan bekerja memungkinkan mengatur jadwal bersama pasangan sehingga bisa mengurangi biaya pengasuhan anak.

(iv) Keleluasaan bekerja meningkatkan semangat, keterlibatan dan komitmen kepada organisasi. Selain mengurangi pergantian pekerja, ketidakhadiran, dan keterlambatan.

(v) Penawaran bekerja jarak jauh dan leluasa meningkatkan peluang mendapatkan pekerja berkualitas di atas rata-rata karena terbangun citra pekerja dapat memilih bekerja sesuai agenda pribadi mereka.

(vi) Teknologi 'çloud memungkinkan pekerja memperoleh data dan informasi dari luar kantor. Bagi beberapa jenis usaha, ini memungkinkan menambah lama jam kantor dan cakupan layanan. Bahkan memungkinkan mempekerjakan pegawai dari lokasi dengan gaji minimum yang lebih rendah dan mengurangi kompensasi tanpa mengurangi kualitas. Selain mengurangi biaya operasi kantor, karena berkurangnya luasan kantor, kebutuhan kursi, meja, komputer, peralatan lainnya. 
Sebagai pembanding, sebuah penelitian yang dilakukan oleh Ohio University USA (Ohio, 2015) menyimpulkan beberapa hal yang sama dan juga berbeda yaitu

(i) Perusahaan Amerika mengenali manfaat dari bekerja leluasa, walaupun banyak yang menganggap hanya menguntungkan pegawai. Bekerja jarak jauh menghemat biaya yang berasal dari pengurangan biaya per pegawai, meningkatkan produktivitas yang menghasilkan lebih banyak pendapatan, dan upah fleksibel.

(ii) Berbeda dengan pandangan umum bahwa bekerja jarak jauh akan mengurangi produktifitas, statistik terkini menunjukkan kondisi sebaliknya. Sebanyak 56 persen mempercayai bahwa pekerja jarak jauh mempunyai produktifitas yang sama dengan pekerja skema biasa, 24 persen meyakini bahwa pekerja jarak jauh lebih produktif.

(iii) Pekerja jarak jauh lebih fokus pada pekerjaannya, bahkan menyediakan waktu lebih banyak dari pada bekerja di kantor. Penelitian menunjukkan pekerja jarak jauh 53 persen lebih banyak bekerja lebih dari 40 jam seminggu. Secara rata-rata, pekerja jarak jauh bekerja lebih banyak 5 (lima) sampai 7 (tujuh) jam dibanding pekerja biasa.

(iv) Sekitar 80 persen pekerja jarak jauh menyatakan bekerja jarak jauh memungkinkan mengatur keseimbangan bekerja-berkehidupan. Keleluasaan yang tersedia memungkinkan mengerjakan urusan pribadi tanpa kehilangan kesempatan bekerja. Kondisi sakit pun masih memungkinkan tidak kehilangan waktu kerja ketika bekerja dari rumah. Kemampuan mengendalikan keseimbangan bekerja-berkehidupan menyumbang pada pengurangan tingkat stres pegawai. Pekerja jarak jauh melaporkan berkurangnya tingkat stres sampai 25 persen.

(v) Perusahaan dimungkinkan menerima pegawai dari berbagai belahan bumi dengan biaya murah melalui wawancara jarak jauh. Perusahaan juga dapat mengurangi biaya melalui pengurangan ruang kantor, alat tulis, pemakaian telepon, dan akomodasi. Sebuah perusahaan dengan 100 pekerja jarak jauh dari rumah menghemat pengeluaran 1 juta USD per tahun. Sebagai contoh, pekerja jarak jauh American Express menghasilkan potensi bisnis lebih besar 43 persen dan Alpine Access meningkat penjualannya sebesar 30 persen dan berkurang keluhannya sebesar 90 persen.

(vi) Pengeluaran perusahaan juga dapat dihemat dari gaji pegawai seperti tunjangan transportasi dan makan yang tidak diperlukan lagi. Pekerja jarak jauh sendiri dapat berhemat dari pengurangan biaya transportasi, makanan, dan biaya terkait lainnya selama perjalanan pergi dan pulang kantor.

(vii) Kepuasan pegawai berkaitan langsung dengan kesetiaan dan tingkat kebetahan pegawai. Pekerja jarak jauh yang memang menyukainya lebih puas dan bertahan. Menurut sebuah penelitian, 76 persen pekerja jarak jauh lebih setia pada perusahaan.

Siddhartha dan Malika (2016) mengelompokkan manfaat dan kerugian bekerja jarak jauh dalam kategori kelebihan dan tantangan berdasar pandangan pekerja dan pemberi kerja. Selengkapnya pada Tabel 1 berikut.

Tabel 1. Kelebihan dan Tantangan Bekerja Jarak Jauh menurut Pekerja dan Pemberi Kerja

\begin{tabular}{|c|c|c|}
\hline Kategori & Kelebihan & Tantangan \\
\hline & $\begin{array}{l}\text { - Mandiri dan leluasa } \\
\text { menentukan jadwal kerja }\end{array}$ & $\begin{array}{l}\text { Kesulitan membedakan antara } \\
\text { waktu kerja dan urusan pribadi }\end{array}$ \\
\hline & $\begin{array}{l}\text { Waktu perjalanan } \\
\text { kekantor berkurang/ } \\
\text { hilang }\end{array}$ & $\begin{array}{l}\text { - Merasa terisolasi dari jejaring } \\
\text { sosial kantor }\end{array}$ \\
\hline & - Biaya perjalanan, dan & - Perangkat tidak lengkap atau \\
\hline
\end{tabular}




\begin{tabular}{|c|c|c|}
\hline \multirow[t]{3}{*}{ Pekerja } & parkir berkurang & kurang dukungan teknis \\
\hline & $\begin{array}{l}\text { - Lebih semangat dan puas } \\
\text { bekerja }\end{array}$ & $\begin{array}{l}\text { Interaksi terbatas dengan } \\
\text { pimpinan yang dapat berdampak } \\
\text { pada karir }\end{array}$ \\
\hline & $\begin{array}{l}\text { - Terhindar dari kasak } \\
\text { kusuk kantor (office } \\
\text { politics) }\end{array}$ & $\begin{array}{l}\text { Merasa tidak disukai oleh rekan } \\
\text { kerja }\end{array}$ \\
\hline \multirow{5}{*}{$\begin{array}{l}\text { Pemberi } \\
\text { Kerja }\end{array}$} & $\begin{array}{l}\text { - Produktifitas pekerja } \\
\text { meningkat }\end{array}$ & $\begin{array}{l}\text { - Kesulitan memantau kinerja } \\
\text { pekerja }\end{array}$ \\
\hline & $\begin{array}{l}\text { - Tingkat ketidakhadiran } \\
\text { berkurang }\end{array}$ & $\begin{array}{l}\text { - Kesulitan mengukur tingkat } \\
\text { produktifitas pekerja }\end{array}$ \\
\hline & $\begin{array}{l}\text { - Masa kerja pekerja } \\
\text { meningkat }\end{array}$ & $\begin{array}{l}\text { - Mendorong perubahan } \\
\text { organisasi keluar dari zona } \\
\text { nyaman }\end{array}$ \\
\hline & $\begin{array}{l}\text { Lebih banyak calon } \\
\text { pegawai yang dapat } \\
\text { dipilih }\end{array}$ & $\begin{array}{l}\text { Peluang dampaknegatif terhadap } \\
\text { jejaring sosial kantor }\end{array}$ \\
\hline & $\begin{array}{l}\text { - Berkurangnya biaya } \\
\text { kantor }\end{array}$ & $\begin{array}{l}\text { - Kesulitan mendorong sinergitas } \\
\text { tim }\end{array}$ \\
\hline
\end{tabular}

Sumber: Siddhartha dan Malika, 2016

Mokhtarian dkk (1998), menggunakan data San Diego, mengategorikan keuntungan bekerja jarak jauh dalam 5 (lima) kategori yaitu (i) manfaat individu, (ii) stres, (iii) keluarga, (iv) cuti orang tua dan (v) relokasi. Sementara kerugian bekerja jarak jauh, yang dikenal sebagai 'kendala internal', diklasifikasikan dalam 4 (empat) kategori, yaitu (i) interaksi tempat kerja, (ii) visibilitas manajemen, (iii) disiplin kantor, dan (iv) manfaat penglaju. Selain itu, kendala eksternal beragam seperti kurangnya kesadaran, ketidaksesuaian pekerjaan dan lainnya (Asgari, 2015).

Penelitian oleh Moen dkk. (2011) menyatakan keleluasaan pegawai mengendalikan waktu kerja dan keleluasaan berinisiatif dapat mengurangi tingkat pergantian pegawai. Meningkatnya competitive advantage, produktifitas, tertariknya talenta hebat adalah juga beberapa manfaat buat pemberi kerja, sementara membaiknya moral pegawai, kualitas hidup, berkurangnya ketidakhadiran yang tak terjadwal sebagai manfaat bagi pegawai (Grobler dan De Bruyn, 2011).

Berbagai penelitian menunjukkan bahwa organisasi/perusahaan mempunyai beragam dasar memperkenalkan bekerja jarak jauh, mulai dari pengurangan biaya dan peningkatan persaingan untuk memacu pegawai, memperkuat kualitas kerja, memperbaiki citra perusahaan dan mempertahankan pegawai berkualitas (Korte, 1996). Selain itu, meningkatkan keseimbangan bekerja dan berkehidupan (work-life balance), memperbesar kemandirian, dan meningkatkan kualitas semangat juang (Half, 2019).

Secara khusus dari sisi pemberi kerja atau organisasi/perusahaan, produktivitas menjadi pendorong fleksibilitas kerja dan mendorong para pekerja dan pemberi kerja tertarik menjalankan skema bekerja jarak jauh (Avery dan Zabel, 2001; Bond dkk., 2005). Setiap kantor berusaha meningkatkan produktivitas, karenanya, pengaturan kerja fleksibel menjadi menarik (Bond dkk., 2005). Pinsonneault and Boisvert (2001) menegaskan bahwa peningkatan produktivitas terkait dengan bekerja jarak jauh tercatat sebagai temuan terbanyak dalam literatur. Dalam risetnya, tercatat 24 penelitian tentang bekerja jarak jauh dan mempunyai dampak positif terhadap pekerja dan pemberi kerja. Penjadwalan kerja fleksibel memungkinkan lebih banyak kerja mandiri, dan berakibat meningkatnya 
produktivitas dan kinerja (Dodd dan Ganster, 1996; Hackman dan Oldham, 1976) dan kepuasan kerja (Cao, 2005; Neufeld, 1997; Thomas dan Ganster, 1995). Pengaturan waktu kerja alternatif seperti flexitime dan kepuasan kerja adalah keterkaitan yang terbanyak diteliti dan salah satu yang dilaporkan paling sering terkait dalam literatur (Pinsonneault dan Boisvert, 2001) (Jackson dan Fransman, 2018).

Pemberi kerja mengadopsi praktek kerja leluasa (flexible work) sebagai alat mencapai efisiensi operasional yang lebih baik (Appiah-Mfodwa dkk., 2000). Kerja leluasa mempunyai peluang menguntungkan pegawai dan juga organisasi melalui dukungan perilaku kerja positip seperti komitmen, motivasi dan kepuasan kerja, dan berkinerja baik (Fransman, 2015; Leslie dkk., 2012; Nadeem dan Henry, 2003).

Bekerja leluasa mendorong skema 'hot-desking' menjadi popular, yang memungkinkan pegawai menggunakan kursi dan komputer secara bergantian pada saat hadir di kantor sehingga membutuhkan luasan kantor lebih kecil karena pegawai dapat bergantian, bahkan jumlah pegawai dapat bertambah tanpa penambahan luasan kantor (Half, 2019).

Banyak pemberi kerja menemukan bahwa peningkatan keleluasaan bekerja tidak menghalangi tingkat produktifitas (Reese, Rowings \& Sharpley 2007). Selain itu, keleluasaan bekerja dan kesejahteraan saling berhubungan. Perusahaan bertanggungjawab menciptakan lingkungan kerja yang menghasilkan kesejahteraan pekerja. Lebih lanjut, kesejahteraan psikologis menjurus pada kesejahteraan mental, keduanya membantu mencapai keseimbangan bekerja-berkehidupan. Temuan lainnya menyatakan bahwa kesejahteraan pegawai secara langsung mempengaruhi produktivitas dan kinerja, sebagaimana juga komitmen, kepuasan kerja, dan keseimbangan bekerja-berkehidupan (Baptiste, 2008).

Namun, keleluasaan kerja tidak selalu memperkuat produktifitas dan kepuasan kerja (Fransman 2015). McGuire and Liro (1986) menyimpulkan dalam penelitiannya bahwa keleluasaan waktu kerja berdampak terbatas terhadap produktifitas kerja. Hartman, Stoner and Arora (1991) melaporkan bahwa gangguan keluarga memengaruhi produktifitas bekerja jarak jauh. Sebagai jalan keluarnya adalah menciptakan jadwal kerja ketika bekerja di rumah, yang disampaikan ke anggota keluarga untuk mengurangi gangguan. Memastikan maksimalnya produktifitas, sewajarnya tersedia alat komunikasi dengan manajer dan rekan kerja. Manajemen dan koordinasi yang baik memungkinkan bekerja jarak jauh (Hartman et al. 1991). Cooper and Kurland (2002) and McCloskey (2001) mengakui bahwa keterasingan sosial dan keterhubungan sosial yang berkurang sebagai akibat bekerja jauh dari kantor dan rekan kerja mungkin mempunyai dampak negatif terhadap kepuasan kerja.

Perusahaan memperkenalkan paket bekerja leluasa (flexible working) sebagai bagian dari kebijakan keseimbangan bekerja-berkehidupan (work-life) dalam rangka menarik, merekrut dan mempertahankan staf berkualifikasi tinggi (Croucher dan Kelliher, 2005). Pekerja yang dapat mengatur jadwal kerjanya merasa bahwa perusahaan peduli terhadap kesejahteraan dan kehidupan sosial pekerja (Casper dan Harris, 2007). Hal ini meningkatkan kepuasan terhadap perkerjaan dan perusahaan, berujung pada meningkatnya komitmen pekerja (Kelliher dan Anderson, 2010). Menurut penelitian terdahulu, bekerja leluasa menghasilkan kesetiaan dan keterlibatan pegawai, meningkatkan komitmen, dan kepuasan terhadap pekerjaan, juga membantu merekrut dan mempertahankan pegawai bertalenta (Anderson dan Kelliher, 2009). Selanjutnya, produktifitas meningkat, pergantian pegawai dan ketidakhadiran berkurang (Anon, 20008). Sehingga, bekerja leluasa bermanfaat bagi perusahaan, oleh karenanya keleluasaan diberikan agar dapat memberi pekerja pilihan untuk memilih sendiri waktu, lama dan lokasi kerja.

Para pekerja menyatakan sendiri beberapa manfaat bekerja jarak jauh, yaitu (i) keseimbangan lebih baik antara kebutuhan kerja-bukan kerja; (ii) kendali lebih baik terhadap waktu dan pola kerja; (iii) meningkatkan keleluasaan terkait kinerja dan produktifitas kerja; (iv) kualitas hidup lebih baik; (v) biaya dan kesulitan pergerakan lebih sedikit; (vi) 
menciptakan bisnis baru; (vii) lebih banyak yang dapat bekerja (Korte, 1996). Hal ini sejalan dengan yang juga disampaikan oleh perusahaan.

Keleluasaan dalam bekerja jarak jauh memungkinkan pekerja menyesuaikan ritme kehidupannya dengan keseharian keluarga serta jenjang karir. Hal ini juga menawarkan kesempatan bagi calon pegawai yang mempunyai kendala fisik atau keluarga. Namun, keadaan ini menciptakan masalah perbedaan antara bekerja dan kehidupan sosial dan keluarga. Dalam kaitan ini, dimensi gender menjadi penting. Pekerja wanita tetap bertanggungjawab atas pekerjaan rumah tangga dan merawat anak termasuk anggota keluarga lain seperti lansia (Huuhtanen, 1997)

Penelitian oleh Galea dkk. (2014) menemukan waktu kerja leluasa sebagai kondisi winwin bagi pegawai dan pemberi kerja, dan menemukan bahwa waktu kerja leluasa merupakan media yang memasilitasi alur transisi antara bekerja dan kehidupan pribadi. Memanfaatkan waktu bekerja leluasa memungkinkan pegawai mengelola prioritasnya langsung, baik menyangkut kebutuhan keluarga maupun pribadi atau keperluan kantor (Fransman 2015).

Bekerja leluasa menjadikan tingkat kepuasan dan motivasi lebih tinggi, serta keseimbangan bekerja-berkehidupan (work-life) yang lebih baik (Fransman 2015; Symanowitz 2012). Selanjutnya, semangat kerja terpicu oleh peningkatan keseimbangan bekerjaberkehidupan yang berdampak pada peningkatan produktifitas dan kinerja (Half, 2019).

Konsep keseimbangan bekerja-berkehidupan memperoleh perhatian berkat keterkaitannya bagi seluruh pekerja tanpa memperhatikan status, ukuran keluarga, dan jumlah anak. Beberapa peneliti memahami bahwa kekurangan keseimbangan adalah sebuah dampak dari pertentangan antara tanggungjawab bekerja dan berkehidupan (Lingard dan Francis, 2009). Penelitian terdahulu menunjukkan bahwa dukungan emosi kepada pekerja selama bekerja mempunyai kaitan positip dengan keseimbangan bekerja-berkehidupan (Abendroth, dan Dulk, 2011). Kaitan positip telah ditemukan antara keseimbangan bekerjaberkehidupan dan kinerja pekerjaan (Lyness dan Judiesch, 2008). Sehingga, keberhasilan pencapaian tanggungjawab berkehidupan (peran keluarga dan orang tua) menghasilkan kinerja pekerjaan lebih baik. Sementara keseimbangan bekerja dan berkehidupan meningkatkan kepuasan hidup secara umum (Cunha dan Rego, 2009).

Keleluasaan bekerja telah diperkenalkan sebagai bermanfaat bagi pekerja sekaligus sebagai orang tua dalam rangka membantu mereka memenuhi tanggungjawab bekerja dan berkehidupan dan mencapai keseimbangan bekerja-berkehidupan (Thompson, 2008). Pada penelitian terakhir, peneliti menemukan bahwa pekerja percaya jika bekerja leluasa meningkatkan moral, yang berdampak positif pada keseimbangan bekerja-berkehidupan; sebagai tambahan pekerja percaya bahwa perusahaan dapat membantu mereka menyeimbangkan peran bekerja dan berkehidupan (Tipping, Chanfreau, dan Tait, 2012). Sebagai contoh, bekerja leluasa merupakan salah satu kegiatan terbaik untuk meningkatkan kesejahteraan pekerja, sehingga membantu pekerja menghadapi tanggungjawab di luar pekerjaan (Pruyne, Powell, dan Parsons, 2012).

Pemahaman terhadap stres berbeda bagi setiap pekerja. Secara umum, stres terjadi karena tiadanya kendali terhadap kapan, dimana, dan bagaimana bekerja (Lockett, 2012). Stres berat berdampak pada kesehatan fisik dan mental termasuk hubungan tidak harmonis dan kurang bahagia yang menyebabkan pertentangan bekerja-berkehidupan (Looker, 2011). Bukti menunjukkan bahwa pekerja yang terganggu keseimbangan bekerja-berkehidupannya mengalami stres yang lebih berat (Lowe, 2006).

Bekerja jarak jauh, sebagaimana tipe bekerja tradisional, tingkat stres, dampak kesehatan, psikologis berbeda tergantung jenis keahlian kerja yang dibutuhkan. Selain itu, kemandirian dan kendali terhadap ritme dan substansi kerja juga berpengaruh. Pada banyak 
kejadian, stres pada bekerja jarak jauh dihubungkan lebih pada jenis pekerjaan dan organisasi dari pada lokasi bekerja (Huuhtanen, 1997)

Secara prinsip, bekerja jarak jauh membuka peluang kemandirian dan memberi peluang berkonsentrasi pada pekerjaan dan mengatur kerja dan jadwal berdasar kriteria sendiri. Peningkatan produktifitas telah dilaporkan pada beberapa penelitian di perusahaan asuransi. Kebebasan individu mengatur ritme kerja ternyata juga mengarah pada kelebihan beban kerja bahkan pada kejadian ekstrim menjadi bekerja 24 jam sehari. Bekerja tanpa henti dapat menyebabkan dampak negatif terhadap kesehatan terutama ketika lingkungan kerja jelek atau jenis pekerjaan yang berulang. Faktor penyebab stres lainnya adalah terkait waktu adalah ketidakmampuan memperkirakan jumlah waktu dan saat pelaksanaan tugas. Perilaku gila kerja (workaholic) menjadi resiko tambahan ketika kendali eksternal tidak tersedia atau pekerja tidak dapat mengendalikan dirinya sendiri (Huuhtanen, 1997)

Pekerja kantor jarak jauh tidak bertanggungjawab atas kenyamanan tempat bekerja tetapi pemberi kerja. Namun bagi pekerja mandiri jarak jauh, kenyamanan tempat kerja menjadi tanggungjawabnya. Kemungkinan desain tempat kerja yang tidak memadai akan lebih mungkin terjadi pada pekerja mandiri jarak jauh (Huuhtanen, 1997)

Pola waktu kerja beragam juga berdampak pada keterasingan fisik dan sosial dari pegawai. Kekhawatiran menyeruak terkait keterasingan fisik pekerja dapat mengarah pada resiko tersingkir dari tempat dan rekan kerja, sementara kerja bersama menjadi penting. Dilain pihak, teknologi komunikasi dan informasi menawarkan potensi baru untuk mendukung, melatih, memandu kondisi ini (Huuhtanen, 1997)

Beragam cara mengelola bekerja jarak jauh tergantung pada budaya kepemimpinan dan pengelolaan, kebijakan perusahaan, dan motif bekerja jarak jauh. Hal ini berdampak pada penyiapan dan pelatihan bekerja jarak jauh, dan pengaturan bekerja jarak jauh serta perjanjian kepegawaian yang disiapkan. Pada kejadian bekerja jarak jauh dikelola secara sukarela, termasuk pilihan bekerja kembali pada tempat kerja konvensional jika diperlukan. Sekali lagi, kondisi pekerja berketerampilan tinggi lebih baik dari pekerja tanpa atau kurang berketerampilan (Huuhtanen, 1997)

Organisasi dengan metode manajemen hirarki tradisional mungkin mempunyai masalah dengan pekerja jarak jauh yang sedang 'out-of-sight-out-of-mind' (tidak berada di sekitar kantor), khususnya jika tugas dan sasaran bekerja jarak jauh tidak jelas. Hal ini dapat mengarah pada penolakan terhadap perubahan oleh manajer menengah. Selain itu, pekerja jarak jauh sendiri mungkin merasa únder managed dan takut terhadap dampak negatifnya (Huuhtanen, 1997).

Belanger (1999) menyebutkan bahwa terdapat 3 (tiga) alasan utama untuk menolak bekerja jarak jauh yaitu kebutuhan bertukar data, lebih produktif bekerja di kantor, dan kebutuhan bersosialisasi dengan rekan kerja. Alasan lainnya keleluasaan waktu bekerja berdampak pada rendahnya kepuasan kerja adalah terbatasnya pengayaan belajar langsung (on-the-job) (Narayanan $\Xi^{2}$ Nath 1982). Penolakan ini yang menjadikan skema bekerja jarak jauh masih diragukan manfaatnya yang kemudian menjadikan banyak para pekerja jarak jauh menjadi lebih bersemangat untuk membuktikan sebaliknya (Half, 2019).

Dipandang dari sudut keinginan pekerja yang tentunya sudah memperhitungkan manfaat dan kerugian bekerja jarak jauh, Belanger (1999) menyimpulkan hasil penelitian empirisnya bahwa (i) kebutuhan berbagi informasi dengan rekan kerja, (ii) lebih produktif pada lingkungan kantor, dan (iii) kebutuhan bersosialisasi dengan rekan kerja adalah 3 (tiga) alasan yang paling sering disebut untuk tidak bekerja jarak jauh (Asgari, 2015).

Mokhtarian dan Niemeier (2000) mencoba mengelompokkan kondisi disukai dan tidak disukai berdasar sudut pandang pekerja dan pimpinan. Pimpinan dan pekerja secara bersama mendasari pandangannya pada faktor biaya, dan kekerapan bekerja. Sementara 
faktor produktifitas hanya menjadi fokus pimpinan, dan pekerja terfokus pada jarak ke kantor.

Bagi pekerja, bekerja jarak jauh lebih disenangi ketika jarak ke kantor jauh, waktu perjalanan menjadi berharga dan lebih penting lagi perusahaan yang menanggung biaya peralatan. Lebih lanjut, manfaat tidak akan melampaui biaya jika pekerja diminta menanggung biaya peralatan. Bagi perusahaan, bekerja jarak jauh disenangi ketika produktifitas dihasilkan oleh pekerja dengan gaji besar dan penghematan sewa ruang dan parkir terwujud. Selengkapnya pada Tabel 2 berikut.

Tabel 2. Perspektif Pekerja dan Pimpinan tentang Hal Disukai dan Tidak Disukai

\begin{tabular}{|c|c|c|}
\hline & Perspektif Pekerja Jarak Jauh & Perspektif Pimpinan \\
\hline $\begin{array}{l}\text { Kondisi } \\
\text { Disukai }\end{array}$ & $\begin{array}{l}\text { - perusahaan menanggung } \\
\text { biaya peralatan } \\
\text { - jarak ke kantor jauh } \\
\text { - kekerapan bekerja jarak } \\
\text { jauh tinggi }\end{array}$ & $\begin{array}{l}\text { - Pekerja menanggung biaya } \\
\text { peralatan } \\
\text { - Produktifitas tinggi } \\
\text { - } \text { Berkurangnya kebutuhan } \\
\text { ruang dan parker }\end{array}$ \\
\hline $\begin{array}{l}\text { Kondisi Tidak } \\
\text { Disukai }\end{array}$ & $\begin{array}{l}\text { - Pekerja menanggung } \\
\text { biaya peralatan } \\
\text { - Jarak ke kantor dekat } \\
\text { - Kekerapan bekerja jarak } \\
\text { jauh rendah } \\
\text { - Bukan pilihan otomatis }\end{array}$ & $\begin{array}{l}\text { - Perusahaan menanggung } \\
\text { biaya peralatan } \\
\text { - Produktifitas rendah } \\
\text { - Tidak berkurang kebutuhan } \\
\text { ruang dan parkir } \\
\text { - Kekerapan bekerja jarak } \\
\text { jauh rendah }\end{array}$ \\
\hline
\end{tabular}

Sumber: Mokhtarian dan Niemeier, 2000

Menilik manfaat dan kerugian, atau biaya dan manfaat, dapat dilakukan dari berbagai perspektif. Shafizadeh dkk. (1998) mengelompokkan berdasarkan kategori publik, swasta dan individu sebagai berikut

Tabel 3. Biaya dan Manfaat (Cost and Benefit) Bekerja Jarak Jauh dari Pandangan Publik, Swasta, dan Individu

\begin{tabular}{|c|c|c|c|}
\hline & & Biaya & Manfaat \\
\hline \multirow[b]{2}{*}{ Publik } & Start-up & $\begin{array}{l}\text { - Pengembangan } \\
\text { pelatihan } \\
\text { - Evaluasi }\end{array}$ & \\
\hline & Ongoing & $\begin{array}{l}\text { - Pelatihan/pemasaran } \\
\text { - Realisasi permintaan }\end{array}$ & $\begin{array}{l}\text { - Berkurangnya perjalanan } \\
\text { - berkurangnya emisi } \\
\text { - Meningkatnya keamanan } \\
\text { jalan raya }\end{array}$ \\
\hline
\end{tabular}




\begin{tabular}{|c|c|c|c|}
\hline & & - Urban sprawl & $\begin{array}{l}\text { - Meningkatnya ekonomi } \\
\text { (kesempatan kerja bagi } \\
\text { penganggur/disabilitas) } \\
\text { - Meningkatnya keamanan } \\
\text { lingkungan permukiman }\end{array}$ \\
\hline \multirow[b]{2}{*}{ Swasta } & Start-up & $\begin{array}{l}\text { - Perencanaan } \\
\text { - Pelatihan/pemasaran } \\
\text { - Perlengkapan }\end{array}$ & \\
\hline & Ongoing & $\begin{array}{l}\text { - Administrasi internal } \\
\text { - Pemasaran/perekrutan } \\
\text { - Pelatihan } \\
\text { - Penggantian peralatan } \\
\text { - Komunikasi } \\
\text { - Berkurangnya } \\
\text { interaksi di tempat } \\
\text { kerja } \\
\text { - Keamanan data }\end{array}$ & $\begin{array}{l}\text { - } \text { menghemat biaya ruang } \\
\text { kantor dan parkir } \\
\text { - } \text { perekrutan (akses } \\
\text { terhadap calon pekerja } \\
\text { terbaik dan pasar tenaga } \\
\text { kerja lebih luas) } \\
\text { - meningkatnya retensi } \\
\text { - meningkatnya } \\
\text { produktifitas (keti- } \\
\text { dakhadiran berkurang, } \\
\text { ketidak-hadiran sakit } \\
\text { berkurang, waktu kerja } \\
\text { lebih panjang, lebih } \\
\text { sedikit gangguan) } \\
\text { - meningkatnya layanan } \\
\text { pelanggan } \\
\text { - pemulihan bencana } \\
\text { - dibutuhkannya hubungan } \\
\text { masya-rakat } \\
\text { - terpenuhinya kualitas } \\
\text { udara/regu-lasi } \\
\text { pengurangan perjalanan }\end{array}$ \\
\hline \multirow[b]{2}{*}{ Individu } & Start-up & $\begin{array}{l}\text { - } \text { dibutuhkan } \\
\text { perlengkapan } \\
\text { - dibutuhkan perangkat } \\
\text { lunak komputer } \\
\text { - meningkatnya tekanan } \\
\text { berkinerja baik } \\
\end{array}$ & \\
\hline & Ongoing & $\begin{array}{l}\text { - } \text { bertambahnya } \text { biaya } \\
\text { ko-munikasi } \\
\text { - } \text { bertambahnya biaya } \\
\text { energi } \\
\text { - bertambahnya biaya } \\
\text { sewa ruang } \\
\text { - berkurangnya } \\
\text { interaksi }\end{array}$ & $\begin{array}{l}\text { - } \text { menghemat waktu } \\
\text { perjalanan } \\
\text { - menghemat biaya } \\
\text { perjalanan } \\
\text { - menghemat biaya lainnya } \\
\text { - meningkatnya keleluasaan } \\
\text { pribadi } \\
\text { - berkurangnya stres }\end{array}$ \\
\hline
\end{tabular}




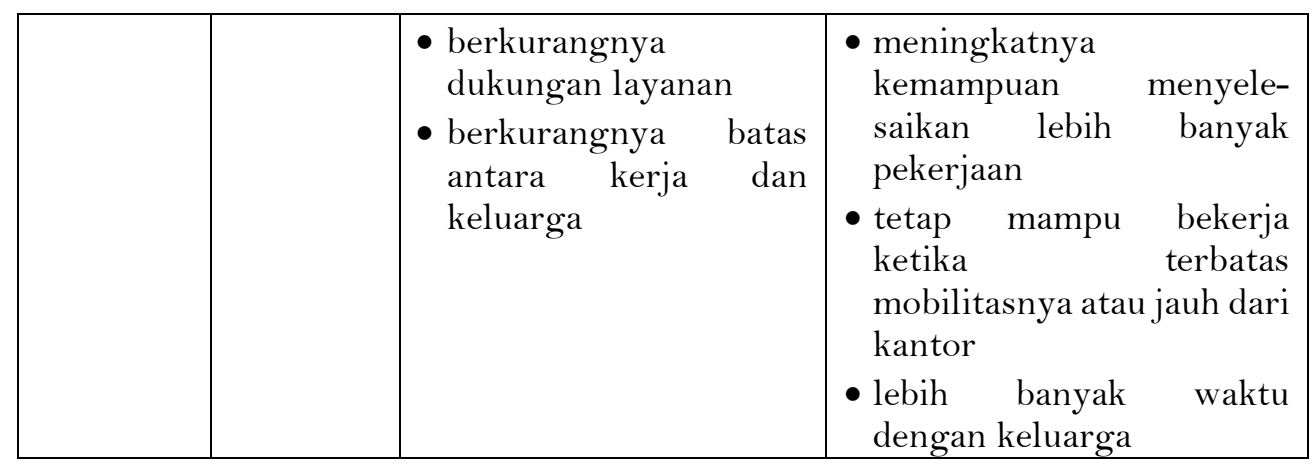

Sumber: Shafizadeh dkk, 1998

Harpaz (2002) melihat manfaat dan kerugian dari sudut pandang pekerja, organisasi, dan sosial sehingga sebutannya pun berubah menjadi kelebihan dan kelemahan bekerja jarak jauh. Selengkapnya pada Tabel berikut.

Tabel 4. Keunggulan dan Kelemahan Bekerja Jarak Jauh dari Pandangan Pekerja, Organisasi dan Sosial

\begin{tabular}{|c|c|c|}
\hline Tingkat & Keunggulan & Kelemahan \\
\hline Pekerja & $\begin{array}{l}\text { - Independensi } \\
\text { - Jam kerja fleksibel } \\
\text { - Peningkatan manajemen } \\
\text { waktu, fleksibilitas beban } \\
\text { kerja } \\
\text { - Hemat waktu dan biaya } \\
\text { perjalanan } \\
\text { - Lebih banyak waktu untuk } \\
\text { keluarga/sosial }\end{array}$ & $\begin{array}{l}\text { - Kurang rasa memiliki } \\
\text { - Timbul perasaan terkungkung } \\
\text { - Hilangnya sekat antara urusan } \\
\text { pekerjaan dan urusan rumah } \\
\text { - Kurang dukungan profesional } \\
\text { - Kemungkinan terhambatnya } \\
\quad \text { karir } \\
\text { - Ketidaknyamanan personal } \\
\text { - Pekerjaan bisa datang kapanpun } \\
\text { - Permasalahan legalitas }\end{array}$ \\
\hline Organisasi & $\begin{array}{l}\text { - Peningkatan produktivitas } \\
\text { - Peningkatan Sumber Daya } \\
\text { Manusia } \\
\text { - Mengurangi absensi dan } \\
\text { keterlambatan } \\
\text { - Penghematan pengeluaran } \\
\text { - Peningkatan motivasi dan } \\
\text { kepuasan } \\
\text { - Muncul kesan positif } \\
\text { terhadap organisasi }\end{array}$ & $\begin{array}{l}\text { - Sulit diterapkan untuk } \\
\text { organisasi dengan manajemen } \\
\text { yang terpusat } \\
\text { - Investasi untuk pelatihan dan } \\
\text { pendampingan } \\
\text { - Kemungkinan pelanggaran } \\
\text { komitmen dan identifikasi } \\
\text { organisasi } \\
\text { - Perubahan metode kerja } \\
\text { - Tambahan biaya untuk transisi } \\
\text { telecommuting } \\
\text { - Permasalahan legalitas } \\
\text { - Timbulnya kerenggangan sosial }\end{array}$ \\
\hline Sos & & \\
\hline
\end{tabular}




\begin{tabular}{|l|l|l|}
\hline & - Mengurangi kerusakan & \\
lingkungan & - Mengurangi kemacetan & \\
- Memenuhi kebutuhan & \\
sosial khusus & - Hemat pengeluaran \\
infrastruktur dan energi & \\
\hline
\end{tabular}

Sumber: Harpaz (2002) dalam Budhiekusuma, Hadi dan Winarno (2017)

Hal lain yang mengemuka bahwa sosialisasi diantara pekerja juga cukup mempengaruhi kinerja bekerja jarak jauh. Gajendran and Harrison (2007) mengungkapkan bahwa lamanya bekerja jarak jauh dan hubungan sesama pekerja mempunyai kaitan negatif. Ini alasan lain bekerja jarak jauh terlalu lama dapat mempengaruhi kinerja. Bekerja jarak jauh dalam waktu singkat tidak berpengaruh pada hubungan sesama pekerja, tetapi bekerja jarak jauh dalam waktu lama mempunyai pengaruh negatif. Semakin kurang hubungan sesama pekerja, semakin sedikit informasi yang diperoleh. Hubungan kuat dengan sesame pekerja penting sebab komunikasi yang sering memudahkan pertukaran informasi. Komunikasi tatap muka menawarkan perpindahan pengetahuan maksimal karena menggunakan saluran komunikasi yang paling mudah menyerap informasi dalam waktu singkat (Wu, Waber, Aral, Brynjolfsson, dan Pentland, 2008).

Pertukaran pengetahuan mengacu pada proses berbaurnya pengetahuan antara individu dalam sebuah organisasi (Taskin dan Bridoux, 2010). Sangat sedikit penelitian terkait dampak bekerja jarak jauh terhadap pertukaran pengetahuan, kecuali oleh Golden dan Raghuram (2010) yang meneliti pekerja jarak jauh selama 6 bulan. Secara umum, hasilnya menunjukkan bahwa penting bagi pekerja jarak jauh menghabiskan waktu di kantor dan bekerja jarak jauh dalam waktu lama dapat mengarah pada berkurangnya pertukaran informasi. Ini berarti hubungan sesama pekerja lebih baik jika mendapat dukungan teknologi dan lebih sering tatap muka.

Berdiskusi penting untuk berbagi informasi dengan sesama pekerja. Namun ketika diskusi berubah menjadi perbincangan maka dapat menjadi salah satu gangguan terhadap proses bekerja. Salah satu alasan bekerja jarak jauh meningkatkan produktifitas karena berkurangnya gangguan selama bekerja terutama jika lingkungan kantor kurang mendukung.

Kepribadian ternyata berpengaruh terhadap dampak bekerja jarak jauh terhadap kinerja pekerja. Terdapat 5 (lima) dimensi kepribadian yang berpengaruh yaitu conscientiousness, extraversion, agreeableness, openness to experience, dan neuroticism (Digman, 1990; McCrae dan Costa, 1987). Ketaatan (conscientiousness) menggambarkan seseorang yang dapat mengendalikan dorongan hati agar berorientasi pada tugas. Mereka mengikuti aturan dan norma. Seseorang yang extraversion bersifat antusias dan tegas. Agreeable menggambarkan seseorang yang berkeinginan bergabung dalam kelompok. Mereka bersifat hangat, mudah percaya, murah hati, fleksibel. Seseorang yang openness to experience bersifat terbuka, dan mempunyai banyak pengalaman hidup. Seseorang yang neuroticism bersifat tidak mudah ditebak, depresi. Kondisi ini relatif tidak stabil.

Pekerja yang taat, kinerjanya tidak dipengaruhi oleh lamanya waktu bekerja jarak jauh. Pekerja yang taat tidak akan menghabiskan waktu melakukan kegiatan di luar pekerjaan walaupun bekerja jarak jauh yang jauh dari pengawasan pimpinan. Ketaatan satusatunya faktor yang berpengaruh terhadap kinerja pekerja. Seseorang dengan sifat ini dapat menyelesaikan tugas tanpa arahan dari pimpinan. Hal ini juga berarti bahwa mereka dapat 
berkinerja bagus tanpa pengawasan dari pimpinan. Dengan demikian, kinerja pekerja yang taat tidak dipengaruhi oleh lamanya bekerja jarak jauh.

Salah satu kekhawatiran terhadap bekerja jarak jauh adalah tiadanya pengawasan sehingga waktu kerja berkurang. Ini dapat mengakibatkan terjadinya cyberloafing yaitu kegiatan memanfaatkan fasilitas internet kantor dalam waktu kerja untuk melaksanakan kegiatan di luar pekerjaan (Lim, Teo, dan Loo, 2002). Namun kesimpulan penelitian lain berlawanan dengan yang selama ini dipahami bahwa makin lama bekerja jarak jauh maka kinerja menjadi menurun. Sementara makin lama bekerja jarak jauh maka makin besar kemungkinan cyberloafing (DeRossette, 2016).

Blanchard and Henle (2008), melaporkan beragam kegiatan cyberloafing yaitu melihat email pribadi (90\%), mengunjungi situs baru (90\%), belanja daring $(70 \%)$, mengunjungi situs olahraga (50\%), memesan paket liburan (50\%), dan mencari kerja $(40 \%)$. Sementara dalam penelitian DeRossette (2016) menunjukkan proporsi yang sedikit berbeda yaitu melihat email pribadi (81.5\%), mengunjungi situs baru $(79.7 \%)$, belanja daring $(65.6 \%)$, mengunjungi situs olahraga $(57.9 \%)$, memesan paket liburan (46.2\%), dan mencari kerja (31.6\%). Dengan demikian, perilaku cyberloafing menjadi perlu mendapat perhatian terkait bekerja jarak jauh. Penelitian ini selanjutnya menunjukkan ketaatan tidak terkait perilaku cyberloafing, namun terkait positip dengan kinerja pekerja. Selain itu, walaupun lamanya bekerja jarak jauh berpengaruh negatif terhadap kinerja pekerja namun batasan lamanya bekerja sendiri belum dapat ditentukan.

Bekerja jarak jauh memperoleh penerimaan lebih baik pada bidang transportasi, kebijakan publik, dan komunitas bisnis, dengan alasan berpotensi sebagai strategi pengelolaan bangkitan lalulintas (Trvael Demand Management/TDM) untuk mengatasi kemacetan dan peningkatan kualitas udara. Pada awal 1990an, perencana transportasi memandang bekerja jarak jauh sebagai sebuah strategi manajemen permintaan perjalanan (Transportation Demand Management/TDM). Sebagai tambahan, bekerja jarak jauh menjadi bagian dari upaya memenuhi Undang-Undang Udara Bersih AS (Clean Air Act). The Clean Air Act Amendments (1990) yang mewajibkan negara memasukkan program pengurangan perjalanan ke tempat kerja dalam rencana pelaksanaannya. Namun, sejumlah pertanyaan masih menggantung terkait dampak bekerja jarak jauh terhadap perjalanan. Dampaknya kompleks, dan tidak selamanya bermanfaat (Salomon, 1985). Meskipun begitu, berbagai penelitian telah menyimpulkan bahwa bekerja jarak jauh mengarah pada pengurangan perjalanan, khususnya pada jam puncak, dan pengurangan emisi nyata (Saxena dan Mokhtarian, 1997).

Pada tahun 1991, the Intermodal Surface Transportation Efficiency Act (ISTEA) memberi keleluasaan lebih besar bagi negara bagian dan pemerintah lokal untuk memenuhi kewajiban ini melalui ukuran permintaan perjalanan (TDMs), seperti bekerja jarak jauh, yang menjadi layak didanai melalui the Congestion Mitigation and Air Quality (CMAQ) Program, selain juga melalui the Surface Transportation Program (STP) (Department of Transportation USA, 1997).

Analisis Keruangan (spatial analysis) dari dampak bekerja jarak jauh terhadap pola perjalanan menjadi penting dikaji dampaknya terhadap energi, kualitas udara, dan guna lahan (Pendyala, Goulias, dan Kitamura, 1991). Pola perjalanan perorangan menjadi penentu utama struktur ruang perkotaan dan guna lahan. Perubahan preferensi keruangan dan perilaku perjalanan menyumbang perubahan struktur ruang kota (Horton dan Reynolds, 1971).

Dampak tidak langsung bekerja jarak jauh yang juga menarik perhatian adalah perpindahan tempat tinggal misalnya berupa berpindah tempat tinggal ke lokasi lebih jauh dengan pertimbangan tidak perlu lagi melakukan perjalanan setiap hari ke tempat kerja. Akibatnya, terdapat potensi bahwa bekerja jarak jauh mendorong fenomena rebakan kota (urban sprawl) (Lund dan Mokhtarian, 1994; Nilles, 1991). Segi positipnya, bekerja jarak jauh 
menjadi kesempatan baru bagi pengembangan kawasan pinggiran dengan menarik pemukim baru (Grimes, 2000; Simpson et al., 2003).

Menariknya, pelaksanaan bekerja jarak jauh tidak membutuhkan penambahan rencana dalam Rencana Tata Ruang, merancangnya hanya membutuhkan waktu singkat dan mudah melaksanakannya dengan bantuan teknologi maju yang tidak perlu mahal.

Terlepas dari keriuhan terkait manfaat, kerugian, tantangan, bahkan dampak bekerja jarak jauh, terdapat satu isu yang perlu mendapat perhatian serius terutama sejak berkembang pesatnya teknologi informai dan telekomuniasi. Bekerja jarak jauh memanfaatkan teknologi agar dapat saling berhubungan antara pekerja dan pimpinan maupun sesama pekerja. Bahkan data dan informasi organisasi atau perusahan dapat dengan mudah diakses oleh pekerja dan pimpinan, tentunya melalui protokol yang ketat. Namun tetap saja, keamanan menjadi isu penting.

Menurut Carnahan dan Guttman (1997), terdapat 3 (tiga) risiko bekerja jarak jauh terkait keamanan, yaitu (i) penyelinap dapat menjangkau sistem organisasi/perusahaan tanpa terdeteksi; (ii) data dan informasi yang sedang dipindahkan melalui jalur internet dapat dengan mudah terbaca, bahkan dimodifikasi; (iii) kehilangan data dan informasi dengan sengaja oleh pihak luar.

\section{Pembelajaran Mancanegara}

Awal konsep bekerja jarak jauh berasal dari Amerika Serikat, namun perkembangannya sendiri tidak luar biasa. Terlepas dari fakta bahwa bekerja dengan waktu kerja tidak leluasa cenderung berdampak buruk pada kesehatan. Bekerja terus menerus dapat berpengaruh pada fungsi mental dan fisik menjadi seperti layaknya mengonsumsi alkohol. Bekerja lebih dari 50 jam seminggu lebih mungkin tiga kali lipat menjadi pecandu alkohol. Akibatnya perekonomian nasional bisa terpengaruh buruk. Para ahli memperkirakan kecanduan alkohol merugikan perekonomian AS sampai 223,5 juta miliar USD setiap tahun. Menurunnya produktifitas menyumbang 72 persen dari kerugian tersebut (Landrum, 2015).

Penelitian tahun 2001 oleh International Telework Association and Council (ITAC) menunjukkan 28,8 juta pekerja jarak jauh di AS, yang berarti pertambahan 17 persen dibanding tahun sebelumnya, dan hampir mencapai satu banding lima pekerja AS. The United States Bureau of Transportation Statistics pada tahun 2006 menunjukkan 30 persen tenaga kerja AS bekerja di rumah setidaknya sekali seminggu (Mello, 2007). Menurut Global workplace analytics and telework research Networks, bekerja jarak jauh regular bertambah 79,7 persen antara 2005 sampai 2012 dan dengan kecepatan yang sama diperkirakan pekerja jarak jauh regular akan mencapai 3,9 juta pada tahun 2016, mencerminkan pertambahan 21 persen dari tahun 2012 yang baru mencapai 3,22 juta pekerja.

Walaupun bekerja jarak jauh dan bekerja leluasa telah menjadi populer, namun dalam kenyataannya pertambahan perusahaan di Amerika Serikat yang menawarkan skema ini hanya sekitar 4-5 persen dalam satu dekade terakhir (Landrum, 2015). Sejalan dengan itu, walaupun terkesan menguntungkan sebagai alternatif cara bekerja namun faktanya, Grobler and De Bruin (2011) mencatat hanya sedikit perusahaan di Afrika Selatan yang pegawainya memanfaatkan pilihan bekerja luar kantor.-Pemanfaatan skema ini oleh pegawai tidak hanya dipengaruhi oleh preferensi mereka tetapi juga oleh persepsi pimpinan (Bianchi dan Milke 2010; Cooke 2005; Downes dan Koekemoer 2011).

Budhiekusuma, Hadi dan Winarno (2017) menuliskan dalam makalahnya tentang beberapa pembelajaran penerapan bekerja jarak jauh di mancanegara seperti India, dan Mesir. Pembelajaran utama terkait alasan dan manfaat penerapan bekerja jarak jauh, yaitu (i) dapat menghemat waktu dan biaya serta mengurangi stres dari penghindaran terhadap kemacetan, (ii) memberikan lebih banyak waktu untuk keluarga. Di India terdapat kebiasaan yang selalu ingin berada dekat keluarga terutama bagi pekerja perempuan yang nota bene 
menjadi semakin dominan, (iii) perbedaan waktu antara pekerja dengan pelanggan yang bisa berada di belahan dunia lain. Keberadaan konsep bekerja jarak jauh membuat waktu kerja lebih fleksibel, (iv) Kemampuan teknologi mobile yang sudah mendekati standar internasional dan sudah mendukung adanya sistem kerja jarak jauh; (v) memberi peluang lebih besar bagi penyandang disabilitas untuk bekerja.

Selanjutnya hasil penelitian di India dan Mesir menunjukkan bahwa manfaat maksimal pelaksanaan bekerja jarak jauh khususnya bagi PNS bisa diperoleh melalui beberapa langkah strategis, yaitu (i) adanya dukungan dari pemerintah dalam bentuk perbaikan regulasi, (ii) peningkatan pemahaman bekerja jarak jauh oleh pihak yang akan dilibatkan dalam pemerintahan termasuk para pengambil kebijakan dan PNS, (iii) menentukan jenis pekerjaan dan tipe PNS yang cocok, (iv) melakukan kajian awal dan menerapkan uji coba terlebih dahulu dalam skala kecil sebelum diimplementasikan secara lebih luas, (v) menetapkan standar kesuksesan implementasi telecommuting dengan mengacu kepada negara maupun unit organisasi/bisnis yang terlebih dahulu dinilai berhasil (Budhiekusuma, Hadi dan Winarno, 2017)

Di Jepang sejak awal, bekerja jarak jauh dikategorikan dalam 3 (tiga) jenis yaitu (i) bekerja dari kantor cabang yang berlokasi dekat rumah atau kantor satelit (satellite offices); (ii) bekerja di rumah (telecommuting); (iii) bekerja di mana saja di luar kantor sesuai kebutuhan (mobile work). Namun berbeda dengan negara lain, pada dekade tahun 90 skema bekerja jarak jauh di Jepang masih belum berkembang dan penerapannya pun sebagian besar dalam bentuk kantor satelit.

Barulah setelah tahun 1995, perusahaan swasta mulai melihat bekerja jarak jauh sebagai bagian dari proses bisnis. Sementara pemerintah Jepang malah baru mulai berinisiatif bekerja jarak jauh setelah tahun 1998. Namun, skema bekerja jarak jauh yang terbanyak adalah bekerja di kantor satelit. Hal ini terutama disebabkan oleh hambatan budaya organisasi perusahaan Jepang. Pegawai selalu berinteraksi langsung bertatapmuka baik di kantor maupun setelah jam kantor. Selain itu, dalam budaya Jepang rumah menjadi kewenangan pengelolaan istri, sehingga keberadaan suami bekerja di rumah akan mengganggu kenyamanan istri. Ditambah pula ukuran rumah Jepang relatif kecil (Higa dan Wijayanayake, 1998).

Berdasar hasil penelitian Higa dan Wijayanayake (1998), faktor berpengaruh terhadap diterapkannya skema bekerja jarak jauh di Jepang adalah

(i) Waktu perjalanan. Lamanya waktu perjalanan mendorong perusahaan mendirikan kantor satelit bagi para pekerjanya

(ii) Harga rumah. Harga rumah di pusat kota sangat mahal dibanding pinggiran kota, sehingga perusahaan lebih memilih menyiapkan kantor satelit bagi pekerja.

(iii) Jenis pekerjaan. Jenis pekerjaan seperti pemasaran dan penyelidikan selalu bekerja berpindah-pindah tanpa melihat ukuran perusahaan

(iv) Ukuran perusahaan. Bagi perusahaan kecil menyiapkan kantor satelit jauh lebih mahal sehingga lebih memilih skema bekerja di rumah.

(v) Budaya organisasi. Budaya bekerja dalam kelompok dan selalu bertatap muka termasuk kebiasaan berkumpul di luar jam kantor menjadi penghalang bekerja di rumah, dan sebagai alternatifnya adalah bekerja di kantor satelit.

(vi) Ukuran rumah. Rumah di Jepang relative kecil, dan sulit menyediakan ruang khusus untuk bekerja. Bekerja di rumah menjadi sulit diterapkan.

Sementara berdasar penelitian Mitomo dan Jitsuzumi (1999) terhadap pengalaman penerapan bekerja jarak jauh di Tokyo, diperkirakan pada tahun 2020 pekerja jarak jauh meningkat dari $14,5 \%$ menjadi $28,3 \%$ yang dapat berpengaruh terhadap kehidupan sosial masyarakat termasuk tingkat pencemaran udara, tingkat konsumsi energi, dan efek rumah kaca. Diperkirakan pada tahun 2010 terjadi penurunan tingkat kemacetan di jalan raya 
sebesar 6,9-10\% akibat implementasi bekerja jarak jauh. Tingkat pengurangan kemacetan ini diperkirakan akan menghemat pengeluaran yang setara dengan $¥ 23$ juta - ¥75 juta per tahun. Hal ini turut dipengaruhi oleh adanya pemberian insentif atau pemotongan pajak terhadap perusahaan yang mendorong implementasi bekerja jarak jauh di lingkungan kerjanya. Selain itu, keberhasilan bekerja jarak jauh di Tokyo Jepang juga didukung dengan adanya regulasi yang tepat (Budhiekusuma, Hadi dan Winarno, 2017).

Beberapa tahun terakhir, Pemerintah Jepang telah aktif mendorong bekerja jarak jauh, namun hasilnya masih belum memadai. Kendala utama tetap seperti beberapa dekade lalu, yaitu budaya perusahaan. Sementara Pemerintah Jepang telah menargetkan 34,5 persen perusahaan telah menerapkan skema bekerja jarak jauh pada tahun 2020.

Perusahaan Jepang sebagian besar tetap percaya bahwa skema bekerja jarak jauh tidak sesuai buat budaya perusahaan. Walaupun beberapa perusahaan telah menerapkan skema ini. Salah satunya adalah perusahaan bumbu masak Ajinomoto Co., yang pekerjanya sekitar 90 persen telah menjalankan bekerja di rumah selama setidaknya 5 (lima) hari sebulan. Hal ini dapat terlaksana ternyata lebih pada komitmen pemimpin perusahaan. Perusahaan menyiapkan perangkat keras berupa telepon pintar dan komputer bagi pekerja. Perusahaan alat kantor Ricoh Co. akan menutup kantor pusatnya selama Olimpiade Tokyo dan menerapkan bekerja di rumah bagi pekerjanya.

Penerapan bekerja di rumah ternyata berdampak berkurangnya komunikasi dan kolaborasi diantara pekerja. Untuk itu, perusahaan menerapkan program pemantauan yang dapat mengamati perilaku pekerja. Selain itu, disiapkan juga kantor satelit bergaya café dengan ruang terbuka.

Bekerja jarak jauh hanya sesuai bagi pekerjaan tertentu. Penelitian Kementerian Transportasi tahun 2018 menegaskan bahwa sekitar 30 persen pekerja industri konsultasi dan riset, informasi dan komunikasi bekerja jarak jauh, sementara hanya 10 persen pada sektor hiburan, perawatan kesehatan, restauran dan hotel. Diperkirakan jika target pemerintah Jepang terpenuhi yaitu sekitar 15,4 persen pekerja menjalankan skema bekerja jarak jauh maka Produk Domestik Bruto Jepang meningkat sebesar 430 juta Yen yang berasal dari pergeseran waktu perjalanan menjadi waktu kerja produktif (Horiuchi, 2020).

Sebuah proyek bernama SUSTEL (Sustainable Teleworking) yang berjangka waktu 2 (dua) tahun melibatkan 5 (lima) negara Eropa yaitu Itali, Denmark, Jerman, Belanda, dan Inggris melaksanakan penelitian terkait dampak ekonomi, lingkungan dan sosial dari skema bekerja jarak jauh.

Secara umum, dampak ekonomi yang positip adalah nilai tambah, sementara aspek lainnya relatif berimbang. Terkait dampak lingkungan, hanya aspek kualitas udara yang positip, dan terlihat aspek sosial yang mempunyai banyak tanggapan positip terkait aspek kualitas hidup, keseimbangan bekerja-berkehidupan, kesehatan dan komunitas. Hasil selengkapnya pada Tabel 5 .

Tabel 5. Dampak Ekonomi Bekerja Jarak Jauh

\begin{tabular}{|c|c|c|}
\hline Aspek & Penilaian & Penjelasan \\
\hline \multicolumn{3}{|c|}{ Dimensi Ekonomi } \\
\hline Nilai Tambah & Positip & $\begin{array}{l}\text { Kinerja meningkat, } \\
\text { ketidakhadiran } \\
\text { berkurang, penerimaan } \\
\text { pegawai membaik dan } \\
\text { bertahan lama. Biaya } \\
\text { perangkat kantor di } \\
\text { rumah bertambah tetapi }\end{array}$ \\
\hline
\end{tabular}




\begin{tabular}{|c|c|c|}
\hline & & $\begin{array}{l}\text { biaya peralatan kantor } \\
\text { berkurang }\end{array}$ \\
\hline Sumberdaya Manusia & Campuran & $\begin{array}{l}\text { Sebagian pekerja } \\
\text { beranggapan } \\
\text { berpengaruh positip } \\
\text { terhadap kompetensi dan } \\
\text { kemahiran. Selebihnya } \\
\text { merasa dampaknya } \\
\text { negatip terhadap karir }\end{array}$ \\
\hline Kesehatan pribadi & Positip Berimbang & $\begin{array}{l}\text { Manfaat finansial seperti } \\
\text { berkurangnya biaya } \\
\text { perjalanan dan } \\
\text { pengasuhan anak } \\
\text { seringkali dikalahkan } \\
\text { biaya listrik rumah } \\
\end{array}$ \\
\hline Ketahanan & Positip Berimbang & $\begin{array}{l}\text { Memungkinkan pekerja } \\
\text { mengurangi gangguan } \\
\text { perjalanan dan lainnya } \\
\text { tetapi rentan terhadap } \\
\text { gangguan sistem. }\end{array}$ \\
\hline \multicolumn{3}{|c|}{ Dimensi Lingkungan } \\
\hline Transportasi & Positip Berimbang & $\begin{array}{l}\text { Terhindar dari } \\
\text { kemacetan dan } \\
\text { perjalanan berkurang }\end{array}$ \\
\hline Kualitas udara & Positip & $\begin{array}{l}\text { Mengurangi perjalanan, } \\
\text { mengurangi emisi. }\end{array}$ \\
\hline Lingkungan Terbangun & Belum Jelas & $\begin{array}{l}\text { Bisa negatip jika } \\
\text { perpindahan kantor tidak } \\
\text { berlokasi dekat } \\
\text { transportasi publik }\end{array}$ \\
\hline \multicolumn{3}{|c|}{ Dimensi Sosial } \\
\hline Inklusi Sosial & Positip Berimbang & $\begin{array}{l}\text { Diskriminasi terhadap } \\
\text { pekerja yang tidak } \\
\text { mempunyai cukup ruang } \\
\text { di rumah }\end{array}$ \\
\hline Kualitas Hidup & Positip & $\begin{array}{l}\text { Meningkat bahkan waktu } \\
\text { kerja bertambah }\end{array}$ \\
\hline $\begin{array}{l}\text { Keseimbangan Bekerja- } \\
\text { Berkehidupan }\end{array}$ & Positip & Meningkat \\
\hline Kesehatan & Positip & $\begin{array}{l}\text { Ketidakhadiran karena } \\
\text { sakit berkurang }\end{array}$ \\
\hline Komunitas & Positip & $\begin{array}{l}\text { Lebih banyak terlibat } \\
\text { dalam kegiatan } \\
\text { komunitas }\end{array}$ \\
\hline
\end{tabular}

Sumber: Avellino, 2005. 
Pada penelitian yang sama didapatkan hasil SWOT (Strength, Weakness, Opportunity, Threat/Kekuatan, Kelemahan, Peluang dan Tantangan) terhadap bekerja jarak jauh. Hal ini jarang dilakukan sehingga menarik untuk menyimak hasilnya. Selengkapnya pada Tabel 6.

Tabel 6. SWOT Bekerja Jarak Jauh

\begin{tabular}{|c|c|}
\hline Kekuatan & Kelemahan \\
\hline 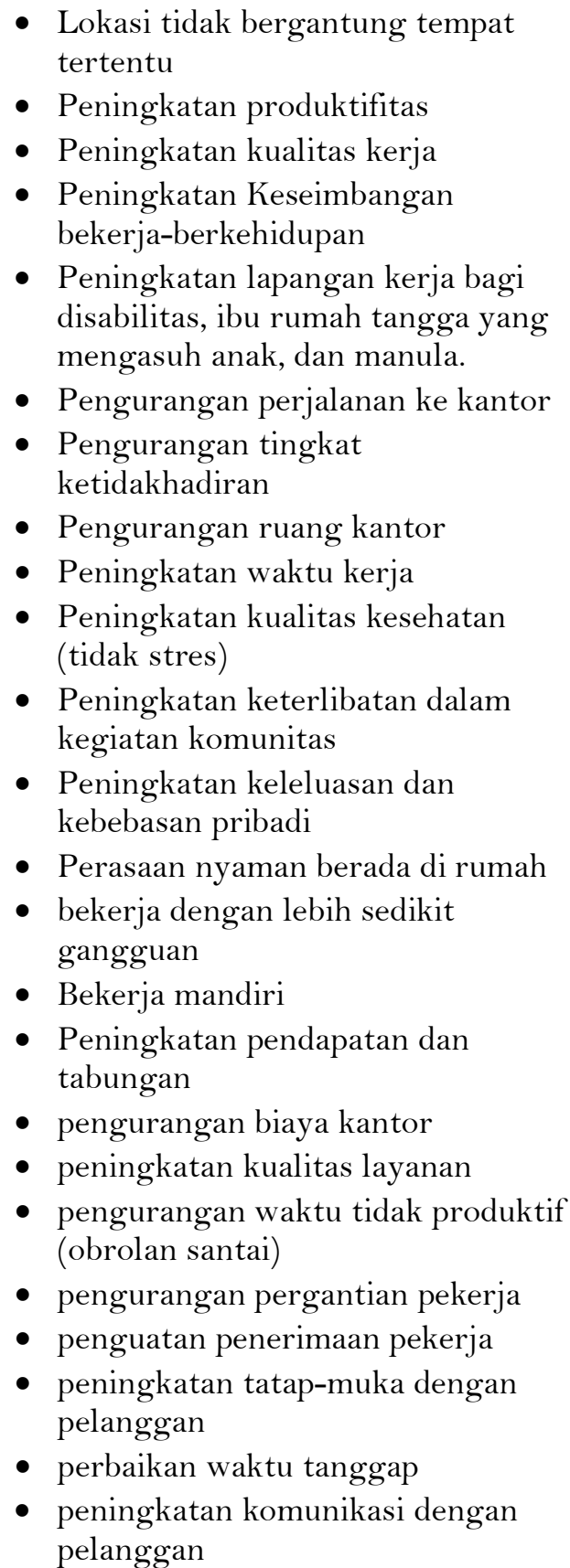 & $\begin{array}{l}\text { - } \text { berkurangnya tatap-muka } \\
\text { - } \text { dengan pekerja lain } \\
\text { berpeluang mengurangi waktu } \\
\text { dengan keluarga, stres, berujung } \\
\text { kualitas hidup menurun. } \\
\text { - } \text { waktu kerja yang tidak tetap } \\
\text { - } \text { terkungkung } \\
\text { - } \text { tidak dapat memisahkan waktu } \\
\text { kerja dengan waktu keluarga } \\
\text { - perjalanan bertambah selain } \\
\text { perjalanan ke kantor } \\
\text { - kehilangan suasana berkelompok } \\
\text { - pimpinan dan pekerja harus } \\
\text { dilatih untuk melakukan } \\
\text { penyesuaian } \\
\text { - masalah kantor dapat bercampur } \\
\text { dengan masalah keluarga } \\
\text { - revisi terhadap strategi bisnis, } \\
\text { konsep teknologi, pembentukan } \\
\text { kelompok, kolaborasi, } \\
\text { - pengelolaan dan pengendalian } \\
\text { - kekuasaan merasa kehilangan } \\
\text { - kantor } \\
\text { duplikasi peralatan kerja di } \\
\text { rumah dan di kantor }\end{array}$ \\
\hline
\end{tabular}




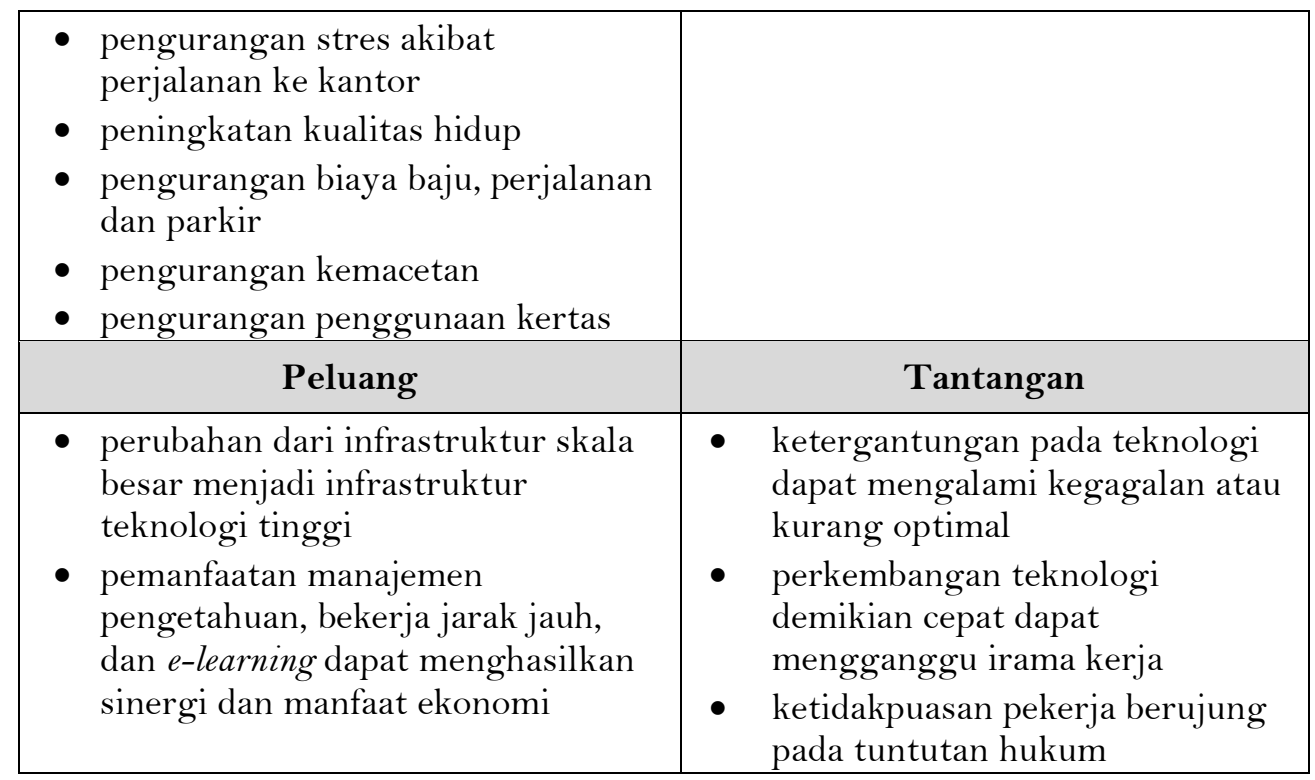

Sumber: Avellino, 2005

Hasil penelitian lain juga menunjukkan hasil yang beragam. Secara umum, hasilnya positif. Sebagai gambaran, Gajendran dan Harrison (2007) menyampaikan terdapat banyak manfaat bekerja jarak jauh berdasar penelitian terhadap 46 hasil studi melibatkan 12 ribu pekerja. Sementara penelitian oleh Bloom, Liang, Roberts, dan Ying (2015) terhadap perusahaan perjalanan Cina menunjukkan bahwa bekerja jarak jauh meningkatkan kinerja sebesar $13 \%$ dan juga peningkatan produktifitas sebesar 4\%. Namun penelitian lainnya terhadap 249 pekerja pemasaran IBM oleh Hill, Miller, Weiner dan Colihan (1998) mengungkapkan bahwa pekerja merasa lebih produktif di rumah dan lebih sedikit gangguan. Sementara penelitian terhadap 25 ribu pegawai IBM dari seluruh dunia menunjukkan hasil yang sedikit berbeda yaitu tidak terlihat perbedaan nyata antara bekerja jarak jauh dan konvensional. Tetapi jelas tidak terdapat penurunan kinerja. Perbedaan hasil penelitian terletak pada metode pengukuran (DeRossette, 2016).

Dari beberapa penelitian di mancanegara, ditemukan beberapa kenyataan yang bertentangan dengan mitos selama ini. Salah satunya dimuat dalam 'Monthly Labor Review' edisi Juni 2013, yang memuat hasil penelitian Professor Glass and Mary C. Noonan, Associate Professor Sosiologi pada The University of Iowa bahwa ternyata 78 persen pekerja jarakjauh bekerja lebih dari 40 jam semiggu. Selain itu, membuat tidak jelas batas bekerja dan kehidupan pribadi. Bekerja jarak jauh kemudian bukannya lebih hemat waktu tapi malah mengambil lebih banyak waktu. Pemahaman bekerja jarak jauh sendiri menjadi bergeser, bukannya bekerja di rumah atau tempat lain pada jam kerja tetapi malah setelah jam kantor (Zimmerman, 2013).

Terkait produktifitas, penelitian Stanford University tahun 2013 menemukan bahwa pekerja 'call center' CTrip (perusaaan perjalanan terbesar Cina) yang mempunyai 16 ribu pekerja, diperbolehkan bekerja dari rumah, menunjukkan peningkatan produktifitas sebesar 13 persen. Pekerja jarak jauh bertambah waktu kerjanya 9 persen, waktu istirahat dan hari sakit lebih sedikit. Demikian juga, tingkat kepuasan meningkat, lebih tenang, dan perilaku lebih positip.

Di lain pihak, bekerja jarak jauh masih merupakan hal baru sehingga masih sering mendapat tantangan dari pelaku bisnis. Bahkan pada tahun 2013, CEO Yahoo memutuskan melarang bekerja jarak jauh bagi pegawainya. Walaupun mendapat banyak kritikan, namun 
kemudian hal ini mendorong timbulnya kesadaran perlunya menyeimbangkan antara lama waktu bekerja jarak jauh (telecommuting intensity) dan konvensional (DeRossette, 2016).

Sementara berdasar pembelajaran di India dan Mesir, ternyata penolakan terhadap konsep bekerja jarak jauh juga dapat digolongkan berdasar sudut pandang pimpinan dan pekerja dalam setidaknya 3 (tiga) kategori, yaitu

(a) Manajemen berupa (i) para manajer menganggap sebagai ancaman terhadap identitas, harga diri dan jabatan; (ii) para manajer merasa terkendala dalam mengendalikan dan menilai secara fisik kegiatan para pekerja,

(b) Pekerja berupa (i) kurangnya dukungan perusahaan yang berdampak terhadap karir; (ii) kurangnya interaksi antarpekerja dan interaksi sosial; (iv) keterbatasan ruang kerja; (v) ketenangan dan kenyamanan kerja sulit diperoleh di rumah yang dipenuhi sanak keluarga; (vi) keterbatasan sinyal dan listrik

(c) Keamanan berupa kemungkinan tidak terlindunginya data dan informasi perusahaan (Budhiekusuma, Hadi dan Winarno, 2017)

Selain itu, untuk lebih memaksimalkan pemanfaatan bekerja jarak jauh maka perlu dilakukan (i) penetapan tujuan pemanfaatan, (ii) penentuan jenis pekerjaan yang sesuai, (iii) memilih tipe pekerja yang cocok, (iv) pemberian pemahaman kepada jajaran organisasi, (v) pelaksanaan uji coba terlebih dahulu dalam skala kecil, (vi) pelaksanaan analisis awal, (vii) penentuan standar kesuksesan implementasi bekerja jarak jauh dengan berpatokan pada praktek unggulan organisasi lain yang dipandang berhasil.

Berdasar penelitian Avellino (2005) pada 5 (lima) negara Eropa terkait langkah yang perlu diambil agar tercapai keberhasilan dalam mengarusutamakan bekerja jarak jauh, maka langkah pertama adalah mengembangkan Rencana Aksi Nasional Bekerja Jarak Jauh yang menggambarkan visi, misi, kebijakan dan strategi, peta jalan dan rencana aksi.

Selajutnya dibutuhkan sebuah Kelompok Kerja yang beranggotakan pemangku kepentingan terkait, baik pemerintah maupun non pemerintah, untuk menyelenggarakan forum pertemuan berkala dalam rangka pelaksanaan Rencana Aksi Nasional. Dibutuhkan sebuah uji coba baik di perusahaan swasta maupun institusi pemerintah sebagai model pelaksanaan skema bekerja jarak jauh. Hasil uji coba akan menjadi masukan bagi pengembangan Kerangka Kebijakan Nasional.

\section{E. Pembelajaran Pribadi Bekerja di Rumah: Sebuah Testimoni}

Praktek bekerja di rumah sebenarnya bukan hal yang baru. Semenjak teknologi memungkinkan, bekerja di rumah dan saling berkirim data dan informasi melalui internet sudah lumrah. Namun kemudian ketika skema bekerja di rumah menjadi resmi ternyata tidak semudah yang selama ini berlangsung.

Sejak beberapa bulan lalu, Bappenas (tempat bekerja penulis) telah meresmikan sistem flexiwork (bekerja di luar kantor) yang memungkinkan staf Bappenas melaksanakan kewajibannya di luar kantor menggunakan aplikasi yang telah dirancang untuk itu. Namun, penulis jarang memanfaatkan skema ini karena merasakan lebih nyaman bekerja di lingkungan kantor dengan berbagai pertimbangan.

Sejak merebaknya virus Corona dan penetapan virus Corona sebagai pandemi yang diikuti dengan keputusan bekerja dari rumah (working from home/WFH) oleh pimpinan maka resmilah penulis melaksanakan skema bekerja dari rumah (flexiwork istilah yang digunakan oleh Bappenas). Seiring berjalannya waktu yang telah memasuki minggu kedua, beberapa pengalaman penulis menjadi menarik diungkapkan melengkapi tulisan ini.

Hal pertama yang terpikirkan ketika memasuki hari pertama WFH adalah menyenangkan bekerja di rumah dengan suasana santai, tersedia makanan, waktu kerja fleksibel, tidak perlu memakai baju kantoran hanya memakai kaos pun cukup, bisa nonton TV, bahkan mendengarkan musik dengan suara keras dimungkinkan. Hanya satu yang 
mungkin kurang nyaman yaitu tidak bisa ke luar rumah kecuali alasan penting (tetapi hal ini lumrah dalam kondisi lock down).

Apakah yang terjadi sesuai harapan? Ternyata tidak tepat sebagaimana yang dibayangkan. Terlepas dari keuntungan tidak perlu melakukan perjalanan ke kantor (kebetulan ke kantor pakai KRL sehingga tidak mengalami stres karena kemacetan), berkurangnya biaya perjalanan, makan siang dan biaya bercengkerama, namun beberapa hal penting patut menjadi perhatian.

Pertama, sinyal internet ternyata tidak stabil sehingga menyulitkan ketika harus berkomunikasi melalui video call atau aplikasi tele conference. Kedua, keluarga baik istri maupun yang lain tidak sepenuhnya memahami maksud WFH. Walaupun akhirnya dapat dibuat mengerti namun dalam prakteknya waktu kerja banyak terganggu oleh ajakan membantu kegiatan domestik/rumah. Untung saja ini kondisi darurat (lock down) sehingga tidak perlu mengantar keluarga ke pasar, mal dan lainnya. Hal ini banyak dibahas dalam berbagai literatur.

Ketiga, suasana kerja sebagaimana di kantor sulit tercipta karena luasan rumah yang kecil sehingga tidak tersedia ruang khusus untuk bekerja. Berbagai kegiatan domestik dengan mudah menjadi sumber gangguan ketika bekerja. Kondisi seperti ini banyak terjadi di negara seperti Jepang yang sebagian besar luasan rumahnya kecil. Ketersediaan kantor satelit atau co-working space di seputar rumah akan sangat membantu. Keempat, dukungan teknis menjadi penting ketika terjadi kendala dengan perangkat keras seperti komputer. Pada hari ketiga dengan tiba-tiba komputer mati dan saya tidak punya kemampuan untuk memperbaiki. Untung saja masih punya komputer cadangan.

Kelima, suasana yang tidak mendukung akhirnya menjadikan waktu kerja lebih lama agar target kerja dapat tercapai. Alih-alih meningkatkan kualitas hubungan dengan keluarga malah waktu istirahat pun berkurang. Keenam, biaya kantor seperti pemakaian pulsa beralih menjadi biaya pribadi. Biaya ini menjadi cukup nyata karena banyaknya percakapan yang dilakukan melalui video call maupun teleconference.

Ketujuh, WFH dalam jangka waktu lama akan berpotensi menghilangkan semangat kerjasama (rasanya berbeda bekerjasama melalui internet dengan bekerjasama tatap muka). Bercengkerama langsung juga menjadi bagian dari bekerja pada akhirnya. Kedelapan, walaupun tidak diungkapkan langsung tetapi terlihat istri kadang merasa tidak nyaman dengan banyaknya komentar dari saya terhadap berbagai kegiatan domestik yang sedang dijalankan.

Kesimpulan sementara, bekerja di rumah sebaiknya tidak dilakukan dalam jangka waktu lama atau bahkan menjadi regular. Sebaiknya hanya pada waktu tertentu saja ketika membutuhkan perubahan suasana, kondisi darurat atau adanya kebutuhan tertentu yang mengharuskan berada di rumah. Selain itu, dibutuhkan persyaratan minimum yang sebaiknya terpenuhi agar WFH menjadi berkualitas.

\section{F. Kesimpulan}

Bekerja Jarak Jauh telah dikenal setidaknya hampir 50 tahun terhitung sejak pertama kali Niles memperkenalkannya pada tahun 1973. Istilahnya sendiri beragam mulai dari telework, telecommuting, flexi work dan lainnya.

Beragam definisi yang pernah diperkenalkan tentang bekerja jarak jauh, namun secara umum dapat diartikan sebagai pekerjaan dilakukan oleh seseorang (pekerja tetap, pekerja mandiri, pekerja rumahan), baik secara khusus maupun waktu tertentu saja, pada lokasi di luar kantor (rumah, kantor satelit, dan berpindah-pindah) menggunakan media telekomunikasi sebagai alat bantu. Terdapat setidaknya 3 (tiga) dimensi yang berlaku terhadap seluruh definisi yaitu tempat/lokasi, waktu/jadwal, dan pemanfaatan teknologi komunikasi dan informasi modern. 
Secara sederhana, bekerja jarak jauh dapat dikategorikan dalam 3 (tiga) jenis yaitu (i) bekerja di rumah (telecommuting); (ii) bekerja dari kantor cabang yang berlokasi dekat rumah atau kantor satelit (satellite offices); (iii) bekerja di mana saja di luar kantor sesuai kebutuhan (mobile work).

Penerapan bekerja jarak jauh telah menjangkau hampir seluruh bagian dunia tetapi perkembangannya masih belum seperti yang diramalkan pada awal maraknya. Hal ini salah satunya disebabkan masih banyak kontroversi seputar manfaat, kerugian, kendala dan dampak sampai saat ini. Selain tentu saja bekerja jarak jauh juga banyak terkait tidak hanya aspek ekonomi, manajemen, teknologi tetapi juga sosial, psikologis, budaya, bahkan gaya hidup.

Penerapan skema bekerja jarak jauh secara empiris lebih banyak dilaksanakan pada perusahaan swasta, walaupun beberapa negara telah juga melaksanakan secara terbatas. Namun ternyata perusahaan swasta pun terbukti masih banyak yang tidak memperkenankan pekerjanya mengikuti skema ini.

Disadari pula bahwa skema bekerja jarak jauh tidak selamanya dapat dilaksanakan berdasar pertimbangan preferensi pekerja, kesiapan perusahaan/organisasi, jenis pekerjaan, dan dukungan teknologi. Sehingga penerapannya perlu disesuaikan dengan kondisi dan bersifat pilihan.

Secara singkat, manfaat bagi pekerja adalah (i) keseimbangan antara bekerja dan kehidupan keluarga; (ii) mengurangi waktu perjalanan ke kantor dan penghematan bahan bakar; (iii) dapat mengendalikan jadwal kerja dan suasana kerja; (iv) dapat memilih bekerja ketika suasana hati sedang baik. Sementara manfaat bagi pemberi kerja adalah (i) mendorong semangat bekerja; (ii) mengurangi kemalasan dan ketidakhadiran; (iii) mengurangi pergantian pekerja; (iv) memperkuat citra perusahaan sebagai tempat bekerja yang ramah keluarga.

Beragam manfaat yang diperoleh dari bekerja jarak jauh dan leluasa bukannya tanpa kendala dan masalah. Bagi pekerja beberapa masalah diantaranya adalah (i) pekerja yang terbiasa dengan suasana kantor konvensional menjadi kesulitan dalam berkoordinasi dengan rekan kerja. Dibutuhkan penjadwalan kerja yang lebih rapi bahkan mungkin perlu ditetapkan waktu tetap untuk berkumpul di kantor; (ii) tidak terlihat batasan jelas antara kantor dan rumah, bahkan cenderung waktu kerja menjadi tanpa batasan; (iii) pekerja jarak jauh dan leluasa cenderung terlihat seperti pengangguran dan berdampak pada hubungan dengan tetangga dan keluarga. Keluarga dan tetangga mungkin menjadi marah ketika pekerja jarak jauh dan leluasa tidak ikut serta dalam pekerjaan rumah tangga dan lingkungan walaupun kenyataannya berada di rumah.

Sementara bagi pimpinan perusahaan/organisasi, beberapa kendala yang mungkin timbul diantaranya adalah (i) beberapa pimpinan mengalami kesulitan menyesuaikan diri terutama bagi pimpinan yang cenderung kurang percaya kepada bawahan; (ii) pada pekerjaan yang membutuhkan intensitas kerjasama kelompok yang tinggi, dibutuhkan pengaturan jadwal pertemuan yang akan merepotkan; (iii) jenis pekerjaan yang membutuhkan bertemu langsung dengan pelanggan hanya memungkinkan bekerja leluasa secara terbatas, tidak mungkin sepanjang waktu berada jauh dari kantor. Sementara ketika hanya sebagian pekerja yang bisa bekerja jarak jauh dan leluasa maka ini akan menimbulkan rasa ketidakadilan diantara pekerja. (iv) beberapa pekerja tidak dapat bekerja tanpa pengawasan. Walaupun demikian, manfaat bekerja jarak jauh dan leluasa mengalahkan kendala yang dihadapi. Selengkapnya rangkuman manfaat, dan kelemahan dapat dilihat pada Tabel 6 .

Tabel 6. Rangkuman Manfaat, dan Kelemahan dari Sudut Pandang Pekerja, Pemberi Kerja dan Masyarakat

Kategori $\quad$ Manfaat/Kelebihan/ $\quad$ Kelemahan/Kekurangan/Tantangan




\begin{tabular}{|c|c|c|}
\hline & Keunggulan & \\
\hline \multicolumn{3}{|c|}{ Dimensi Ekonomi - Manajemen } \\
\hline \multirow{7}{*}{ Pekerja } & $\begin{array}{l}\text { - mandiri dan leluasa } \\
\text { menentukan jadwal } \\
\text { kerja }\end{array}$ & $\begin{array}{l}\text { terbatasnya pengayaan belajar } \\
\text { langsung (on-the-job) dan } \\
\text { berkurangnya transfer pengetahuan } \\
\text { secara langsung }\end{array}$ \\
\hline & $\begin{array}{l}\text { - waktu perjalanan } \\
\text { kekantor berkurang/ } \\
\text { hilang }\end{array}$ & $\begin{array}{l}\text { Interaksi terbatas dengan pimpinan } \\
\text { yang dapat berdampak pada karir }\end{array}$ \\
\hline & $\begin{array}{l}\text { - biaya perjalanan, dan } \\
\text { parkir berkurang }\end{array}$ & $\begin{array}{l}\text { - merasa terisolasi dari jejaring sosial } \\
\text { kantor }\end{array}$ \\
\hline & $\begin{array}{l}\text { lebih semangat, } \\
\text { komitmen bekerja } \\
\text { meningkat dan } \\
\text { tingkat kepuasan } \\
\text { kerja membaik }\end{array}$ & $\begin{array}{l}\text { - merasa tidak disukai oleh rekan } \\
\text { kerja }\end{array}$ \\
\hline & $\begin{array}{l}\text { - terhindar dari kasak } \\
\text { kusuk kantor (office } \\
\text { politics) }\end{array}$ & $\begin{array}{l}\text { - biaya rumah tangga bertambah baik } \\
\text { listrik, pulsa, dan lainnya }\end{array}$ \\
\hline & $\begin{array}{l}\text { meningkatkan } \\
\text { kompetensi dan } \\
\text { kemahiran }\end{array}$ & $\begin{array}{l}\text { - duplikasi peralatan kerja di rumah } \\
\text { dan di kantor }\end{array}$ \\
\hline & $\begin{array}{l}\text { peningkatan } \\
\text { pendapatan dan } \\
\text { tabungan }\end{array}$ & $\begin{array}{l}\text { - tidak tersedia cukup ruang dan } \\
\text { suasana yang mendukung untuk } \\
\text { bekerja di rumah }\end{array}$ \\
\hline \multirow{6}{*}{$\begin{array}{l}\text { Pemberi } \\
\text { Kerja }\end{array}$} & $\begin{array}{l}\text { - produktifitas pekerja } \\
\text { dan kualitas } \\
\text { pekerjaan meningkat }\end{array}$ & $\begin{array}{l}\text { manajer menganggap sebagai } \\
\text { ancaman terhadap identitas, harga } \\
\text { diri dan jabatan }\end{array}$ \\
\hline & $\begin{array}{l}\text { - tingkat } \\
\text { ketidakhadiran dan } \\
\text { keterlambatan } \\
\text { berkurang }\end{array}$ & - kesulitan memantau kinerja pekerja \\
\hline & $\begin{array}{l}\text { masa kerja pekerja } \\
\text { meningkat terutama } \\
\text { pekerja berkualitas }\end{array}$ & $\begin{array}{l}\text { - kesulitan mengukur tingkat } \\
\text { produktifitas pekerja }\end{array}$ \\
\hline & $\begin{array}{l}\text { - berkurangnya biaya } \\
\text { kantor }\end{array}$ & $\begin{array}{l}\text { - mendorong perubahan organisasi } \\
\text { keluar dari zona nyaman }\end{array}$ \\
\hline & $\begin{array}{l}\text { pekerja } \\
\text { dimungkinkan } \\
\text { bertambah tanpa } \\
\text { menambah luasan } \\
\text { kantor }\end{array}$ & $\begin{array}{l}\text { - sulit diterapkan untuk organisasi } \\
\text { dengan manajemen yang terpusat }\end{array}$ \\
\hline & $\begin{array}{l}\text { - pemanfaatan } \\
\text { manajemen } \\
\text { pengetahuan, bekerja } \\
\text { jarak jauh, dan } e \text { - }\end{array}$ & - kesulitan mendorong sinergitas tim \\
\hline
\end{tabular}




\begin{tabular}{|c|c|c|}
\hline & $\begin{array}{l}\text { learning dapat } \\
\text { menghasilkan sinergi } \\
\text { dan manfaat ekonomi }\end{array}$ & \\
\hline & & $\begin{array}{l}\text { - peluang berdampak negatif } \\
\text { terhadap melemahnya jejaring } \\
\text { sosial kantor }\end{array}$ \\
\hline & & $\begin{array}{l}\text { - belum dilengkapi legalitas bekerja } \\
\text { jarak jauh }\end{array}$ \\
\hline & & $\begin{array}{l}\text { - tambahan biaya untuk transisi } \\
\text { termasuk untuk pelatihan dan } \\
\text { pendampingan }\end{array}$ \\
\hline \multicolumn{3}{|c|}{ Dimensi Lingkungan - Teknologi } \\
\hline \multirow[t]{2}{*}{ Pekerja } & $\begin{array}{l}\text { memungkinkan } \\
\text { dengan teknologi } \\
\text { memperoleh data dan } \\
\text { informasi dari luar } \\
\text { kantor }\end{array}$ & $\begin{array}{l}\text { - tidak tersedia atau kualitas internet } \\
\text { kurang memadai }\end{array}$ \\
\hline & & $\begin{array}{l}\text { - perangkat tidak lengkap atau } \\
\text { kurang dukungan teknis }\end{array}$ \\
\hline \multirow[t]{3}{*}{$\begin{array}{l}\text { Pemberi } \\
\text { Kerja }\end{array}$} & $\begin{array}{l}\text { - } \text { ketersediaan } \\
\text { teknologi } \\
\text { memungkinkan } \\
\text { memantau kegiatan } \\
\text { dan target pekerja } \\
\text { secara langsung } \\
\end{array}$ & $\begin{array}{l}\text { keamanan data dan informasi } \\
\text { perusahaan dapat terancam }\end{array}$ \\
\hline & $\begin{array}{l}\text { pengurangan } \\
\text { penggunaan kertas }\end{array}$ & $\begin{array}{l}\text { - perkembangan teknologi demikian } \\
\text { cepat dapat mengganggu irama } \\
\text { kerja }\end{array}$ \\
\hline & & $\begin{array}{l}\text { - ketergantungan pada teknologi } \\
\text { dapat mengalami kegagalan atau } \\
\text { kurang optimal }\end{array}$ \\
\hline \multirow[t]{3}{*}{ Masyarakat } & $\begin{array}{l}\text { berkurangnya emisi } \\
\text { dan kualitas udara } \\
\text { membaik }\end{array}$ & $\begin{array}{l}\text { - mendorong fenomena rebakan kota } \\
\text { (urban sprawl) }\end{array}$ \\
\hline & $\begin{array}{l}\text { - strategi pengelolaan } \\
\text { bangkitan lalulintas } \\
\text { (Trvael Demand } \\
\text { Management/TDM) }\end{array}$ & \\
\hline & $\begin{array}{l}\text { - tidak membutuhkan } \\
\text { penambahan rencana } \\
\text { dalam Rencana Tata } \\
\text { Ruang }\end{array}$ & \\
\hline \multicolumn{3}{|c|}{ Dimensi Sosial } \\
\hline & $\begin{array}{l}\text { mengurus } \\
\text { kepentingan keluarga } \\
\text { dan berkehidupan }\end{array}$ & $\begin{array}{l}\text { kesulitan membedakan antara } \\
\text { waktu kerja dan urusan pribadi }\end{array}$ \\
\hline
\end{tabular}




\begin{tabular}{|c|c|c|}
\hline \multirow[t]{4}{*}{ Pekerja } & dengan lebih nyaman & \\
\hline & $\begin{array}{l}\text { terhindar dari stres } \\
\text { menghadapi } \\
\text { kemacetan }\end{array}$ & $\begin{array}{l}\text { - bekerja lebih lama dari waktu } \\
\text { standar }\end{array}$ \\
\hline & $\begin{array}{l}\text { - mengurangi biaya } \\
\text { pengasuhan anak }\end{array}$ & \\
\hline & $\begin{array}{l}\text { - berpeluang lebih } \\
\text { banyak terlibat dalam } \\
\text { kegiatan komunitas }\end{array}$ & \\
\hline \multirow[t]{2}{*}{$\begin{array}{l}\text { Pemberi } \\
\text { Kerja }\end{array}$} & $\begin{array}{l}\text { menerima pegawai } \\
\text { dari berbagai daerah } \\
\text { tanpa terikat } \\
\text { pertimbangan } \\
\text { geografis }\end{array}$ & \\
\hline & $\begin{array}{l}\text { meningkatkan citra } \\
\text { perusahaan }\end{array}$ & \\
\hline \multirow[t]{3}{*}{ Masyarakat } & $\begin{array}{l}\text { - berpeluang } \\
\text { menciptakan bisnis } \\
\text { baru }\end{array}$ & $\begin{array}{l}\text { tercipta geger budaya (cultural } \\
\text { schock) berupa kesan menjadi } \\
\text { pengangguran, dan perubahan } \\
\text { kebiasaan keluarga, tetangga dan } \\
\text { komunitas yang belum siap. }\end{array}$ \\
\hline & $\begin{array}{l}\text { peluang kerja lebih } \\
\text { besar bagi disabilitas, } \\
\text { ibu yang sedang } \\
\text { mengasuh balita dan } \\
\text { senior }\end{array}$ & \\
\hline & $\begin{array}{l}\text { - meningkatnya } \\
\text { keamanan jalan raya }\end{array}$ & \\
\hline
\end{tabular}

Sumber : diolah dan dirangkum dari berbagai hasil penelitian

Penerapan skema bekerja jarak jaug berskaa luas membutuhkan langkah strategis berupa

(i) dukungan komitmen pemerintah dalam bentuk penyediaan dan pengembangan regulasi berikut pendukungnya diantaranya berupa insentif bagi perusahaan dan atau institusi pemerintah.

(ii) Pembentukan Forum Bekerja Jarak Jauh Nasional sebagai wadah kolaborasi pemangku kepentingan terkait baik pemerintah maupun non pemerintah, yang diantaranya berfungsi dalam (a) pelaksanaan kajian awal berikut upaya uji coba skala terbatas baik di institusi pemerintah maupun swassta; (b) pemantauan dan peninjauan hasil uji coba dan kemungkinan penerapannya skala luas; (c) penyusunan Rencana Aksi Nasional Bekerja Jarak Jauh, yang menggambarkan visi, misi, kebijaka dan strategi, peta jalan, berikut dokumen pendukungnya baik petunjuk umum maupun petunjuk teknis, melalui pendekatan tata kelola kolaboratif; (d) pengembangan strategi komuikasi publik; (e) pemantauan dan peninjauan penerapan Bekerja Jarak Jauh skala luas; (f) pengembangan kerjasama dengan negara lain dalam pembelajaran penerapan skema ini.

Sebagai penutup, penerapan skema bekerja jarak jauh bukan merupakan pengganti skema bekerja konvensional tetapi lebih merupakan pelengkap. Selain itu, tidak semua jenis 
pekerjaan berkesesuaian dengan skema bekerja jarak jauh. Bahkan karena dampak sosialnya yang cukup besar, penerapan skema bekerja jarak jauh sebaiknya merupakan pilihan dan bukan kewajiban.

\section{Referensi}

\section{Utama}

Asgari, Hamidreza, 2016. On the Impacts of Telecommuting over Daily Activity/Travel Behavior: A Comprehensive Investigation through Different Telecommuting Patterns. Disertasi, Florida International University. Florida International University, 2015.

https://digitalcommons.fiu.edu/etd/2182 diakses pada tanggal 30 Januari 2020.

Ayuna, 2019. Flexi Time: Jenis, Aturan, dan Keuntungannya bagi Karyawan. https://sleekr.co/blog/flexi-time-bagi-karyawan/ diakses pada tanggal 8 Januari 2019.

Budhiekusuma, Noor Patria, Hadi, Sasongko Pramono, dan Winarno, Wing Wahyu, 2017. Peluang Pemanfaatan Telecommuting dalam Pemerintahan di Indonesia. Jurnal Pekommas, Vol. 2 No. 2, Oktober 2017.

DeRossette, Zachary Glenn, 2016. Variation in Job Performance Among Telecommuters. A thesis submitted to the faculty of San Francisco State University. San Francisco, California.

Half, Robert, 2019. Flexible working hours: 7 benefits your business is missing out on https://www.roberthalf.com.sg/ blog/employers/flexible-working-hours-7benefits-your-business-missing-out diakses pada 8 Januari 2020.

Heathfield, Susan M., 2019. The Pros and Cons of a Flexible Work Schedule. https://www.thebalancecareers.com/ advantages-and-disadvantages-of-flexiblework-schedules-1917964\# \#mployee-commute diakses pada 13 Januari 2020

Huuhtanen P., 1997. The health and safety issues for teleworkers in the European Union. Consolidated report. European Foundation for the Improvement of Living and Working Conditions. Working Paper No:WP/97/29/EN.

Jackson. L.T.B. and Fransman, E.I., 2018, 'Flexi work, financial well-being, work-life balance and their effects on subjective experiences of productivity and job satisfaction offemales in an institution of higher learning, South African Journal of Economic and Management Sciences 21(1), a1487. https://doi.org/10.4102/ sajems.v21i1.1487

Jackson, Paul J. dan Wielen, Jos M. Van Der ed., 1998. Teleworking: International Perspectives. From Telecommuting to the Virtual Organisation. Routledge, London and New York.

Kurland, Nancy B. dan Bailey, Diane E., 1999. Telework: the Advantages and Challenges of Working Here, There, Anywhere, and Anytime. Organizational Dynamics, Autumn.

Korte, W., 1996. The Social Implications of Telework. Penetration, Potential and Practice of Telework as well as Labour Law, Social Security, Occupational Health and Safety Issues in Telework and Possible Actions. Conference Document, 22 April 1996, Brussels.

Landrum, Sarah, 2015. Why Flexible Working Hours Make Employees More Productive. Inc. This Morning newsletter. https://www.inc.com/women-2/why-flexible-workinghours-actually-makes-employees-more-productive.html diakses pada 8 Januari 2020

Mokhtarian, Patricia L. dan Niemeier, Deb, 2000. The Costs and Benefits of Home-Based Telecommuting. Georgia Institute of Technology dan dapat diakses pada https://www.researchgate.net/publication/46439032

Ohio University, 2015. Telecommuting Can Save Business Money. Online Master of Business Administration. https://onlinemasters.ohio.edu/blog/how-telecommuting-can-savebusinesses-money/diakses pada 9 Januari 2020 
Saxenaa, Samitra dan Mokhtarian, Patricia L., 1997. The Impact of Telecommuting on the Activity Space of Participants. Geographical Analysis, Vol. 29, No. 2, April 1997, The Ohio State University Press.

Shafizadeh, Kevan R., dkk., 2000. The Costs and Benefits of Home-Based Telecommuting. California PATH Research Report

\section{Pendukung}

Appiah-Mfodwa, A., Horwitz, F., Kieswetter, G., King, D. \& Solai, L., 2000, 'Flexible work practices, productivity improvement and employment', Society in Transition 31(2), 95-1 10. https://doi.org/10.1080/21528586.2000.10419016

Avellino, Marie, 2005. An Enabling Framework for Telework. Research Project for The Employment and Training Corporation, Hal Far.

Avery, C. \& Zabel, D., 2001, The flexible workplace: A sourcebook of information and research, Greenwood Publishing Group, Westport, CT.

Bagley, Michael N., Jill S. Mannering, and Patricia L. Mokhtarian (1994). Tekcommuting Centers and Related Concepts: A Review of Practice. Research Report UCD-ITS-RR-944, Institute of Transporta- tion Studies, University of California, Davis, March.

Belanger, F., 1999. “Workers' Propensity to Telecommute: An Empirical Study". Journal of Information and Management, 35(3), pp. 139-153.

Bianchi, S.M. and Milkie, M.A., 2010, 'Work and family research in the first decade of the 21 st century, Journal of Marriage and Family 72(1), 705-725. https://doi.org/10.1111/j.1741-3737.2010.00726.x

Bond, J.T., Galinsky, E., Kim, S.S. \& Brownfield, K., 2005, National study of employers, http://www.familiesandwork.org/site/research/reports/2005nse.pd diakses pada 12 Agustus 2014.

Carnahan, Lisa J. Dan Guttman, Barbara, 1997. Information Technology Laboratory, National Institute of Standards and Technology.

Cao, F., 2005, 'Exploring the relations among availability of temporal flexibility at work, work-tofamily conflict, and job satisfaction', ProQuest Digital dissertations. (UMI No. 3204652).

Cooke, G.B., 2005, 'The nature and incidents of non-standard work arrangements', Unpublished Master's dissertation, McMaster University, Ontario, Canada.

Cooper, C.D. \& Kurland, N.B., 2002, 'Telecommuting, professional isolation, and employee development in public and private organizations, Journal of Organizational Behavior 23(4), 511-532. https://doi.org/10.1002/job.145

Crimando, W. and S.H. Godley, 1985. "The Computer's Potential in Enhancing Employment Opportunities of Persons with Disabilities". Rehabilitation Counseling Bulletin, 28, pp. 275-282.

De Marco, A., 1995. “The Dawning of the Telecommuter Age”. Facilities Design and Management,.

Dodd, N.G., \& Ganster, D.C., 1996, 'The interactive effects of variety, autonomy, and feedback on attitudes and performance, Journal of Organizational Behavior 17, 329-347. https://doi.org/10.1002/(SICI) 1099-1379(199607)17:4<329::AIDJOB754>3.0.CO;2-B

Downes, C. \& Koekemoer, E., 2011, 'Work-life balance policies: Challenges and benefits associated with implementing flexitime, SA Journal of Human Resource Management 9(1), 1-13. https://doi.org/10.4102/sajhrm.v9i1.382

Force, M. S. (2000). Telecommuting. The Government Accountants Journal, 49(I), 4.

Fransman, E.I., 2015, 'Determining the impact of flexible work hours on women employed in a higher education institution, Unpublished MBA dissertation, North-West University, Potchefstroom. 
Galea, C., Houkes, I. dan De Rijk, A., 2014, 'An insider's point of view: How a system offlexible working hours helps employees to strike a proper balance between work and personal life', The International Journal of Human Resource Management 25(8), 1090-1111. https://doi.org/10.1080/09585192.2013.816862

Grobler, P.A. dan De Bruyn, A.J., 2011, 'Flexible work practices (FWP): An effective instrument in the retention of talent: A survey of selected JSE-listed companies', South African Journal of Business Management 42(4), 63-78.

Hackman, J.R. \& Oldham, G.R., 1976, 'Motivation through the design of work: Test of a theory', Organizational Behavior and Human Performance 16, 250-279. https://doi.org/10.1016/0030-5073(76)90016-7

Handy, S.L., and P.L. Mokhtarian, 1995. "Planning for Telecommuting: Planning and Policy Issues". Journal of the American Planning Association 61(1), pp. 99-111.

Harpaz, I. (2002). Advantages and disadvantages of telecommuting for the individual, organization and society. Work Study, 51(2), 74-80. http://doi.org/10.1108/00438020210418791

Hartman, R.I., Stoner, C.A. \& Arora, R., 1991, 'An investigation of selected variables affecting telecommuting productivity and satisfaction', Journal of Business and Psychology 6(2), 207225. https://doi.org/10.1007/BF01126709

Higa, Kunihiko dan Wijayanayake, Janaka, 1998. Telework in Japan: Perception and Implementation. Tokyo Institute of Technology.

Hill, J.E., Hawkins, A.J., Ferris, M. \& Weitzman, M., 2001, 'Finding an extra day a week: The positive influence of perceived job flexibility on work and family life balance', Family Relations 50(1), 49-58. https://doi.org/10.1111/j.1741-3729.2001.00049.x

Horiuchi, Junko, 2020. Japan Corporate Culture Remain Obstacle to Expansion of Telework. Kyodo News, Jan 3.

Leslie, L.M., Manchester, C.F., Park, T. dan Mehng, S.I., 2012, 'Flexible work practices: $A$ source of career premiums or penalties?', Academy of Management Journal 55(6), 14071428. https://doi.org/10.5465/amj.2010.0651

Mccloskey, D.W., 2001, 'Telecommuting experiences and outcomes: Myths and realities', in N.J. Johnson (ed.), Telecommuting and virtual offices: Issues and opportunities, pp. 231-246, Idea Group, Hershey, PA.

Mello, J., 2007. "Managing Telework Programs Effectively”. Employee Responsibilities and Right Journal, 19(4), pp. 247-261.

Mitomo, H., \& Jitsuzumi, T. (1999). Impact of telecommuting on mass transit congestion: The Tokyo case. Telecommunications Policy, 23(10-11), 741-751. http://doi.org/10.1016/S0308-5961(99)00059-2

Mokhtarian, P.L., 1991. "An Empirical Analysis of the Transportation Impacts of Telecommuting". Proceedings (Vol. 1), 6th International Conference on Travel Behavior, Quebec City, Quebec.

Mokhtarian, P.L., 1998. "A Synthetic Approach to Estimating the Impacts of Telecommuting on Travel'. Urban Studies, 35(2), pp. 215-241.

Moen, P., Kelly, E.L., Tranby, E. \& Huang, Q., 2011, 'Changing work, changing health: Can real work-time flexibility promote health behaviors and well-being?', Work and Health 52(4), 404-429. https://doi.org/10.1177/0022146511418979

Nadeem, S. \& Henry, C., 2003, 'Power dynamics in the long-term development of employee-friendly flexible working', Women in Management Review 18(1/2), 32-49. https://doi.org/10.1108/09649420310462316

Narayanan, V.K. \& Nath, R., 1982, 'Hierarchical level and the impact of flexitime', Industrial Relations 21, 216-230. https://doi.org/10.1111/j.1468-232X.1982.tb00229.x

Neufeld, D.J., 1997, 'Individual consequences of telecommuting', Unpublished doctoral dissertation, University of Western Ontario, Ontario, Canada. 
Nilles, J.M., 1988. “Traffic Reduction by Telecommuting: A Status Review and Selected Bibliography”. Transportation Research, 22 A, pp. 301-317

Nilles, J.M., 1994. "Making Telecommuting Happen: A Guide for Telemanagers and Telecommuters". Van Nostrand Reinhold, New York.

Nilles, J.M., Carlson, F.R., Paul, G.Jr. and G.J. Hanneman, 1974. "Development of policy on the Telecommunications-Transportation Tradeoff". University of Southern California and the National Science Foundation, Report NSF-RA-5-74-020.

Noonan, Mary C. dan Glass, Jennifer L., 2012. The hard truth about telecommuting. Monthly Labor Review, June 2012

Pinsonneault, A. dan Boisvert, M., 2001, 'The impacts of telecommuting on organizations and individuals: A review of the literature', dalam N.J. Johnson (ed.), Telecommuting and virtual offices: Issues and opportunities, pp. 163-185, Idea Group Publishing, Hershey, PA.

Potter, E. E., 2003. Telecommuting: The future of work, corporate culture, and American society. Journal of Labor Research, 24, 73-84. http://doi.org/10.1007/s12122-003-1030-1

Purvanova, R.K., 2014, 'Face-to-face versus virtual teams: What have we really learned?', Psychologist-Manager Journal 17(1), 2-29. https://doi.org/10.1037/mgrooooo09

Raghuram, S. (2014). Telecommuting in India: Pitfalls and Possibilities. South Asian Journal of Human Resources Management, 1(2), 207-220. http://doi.org/10.1177/2322093714549108

Reese, M.P., Rowings, L. \& Sharpley, T., 2007, 'Employee benefits of the future', Employee Benefit Plan Review 61(7), 21-25.

Sampath S., Saxena S. and P.L. Mokhtarian, 1991. "The Effectiveness of Telecommuting as a Transportation Control Measure". Working paper, UCTC No. 78, University of California at Davis.

Siha, S. M., \& Monroe, R. W. (2006). Telecommuting's past and future: a literature review and research agenda. Business Process Management Journal, 12(4), 455-482. http://doi.org/10.1108/14637150610678078

Teo, T.S.H., Lim, V.K.G. and S.H. Wai, 1998. "An Empirical Study of Attitudes towards Teleworking among Information Technology Personnel”. International Journal of Information Management, 18(5), pp. 329-343.

Thomas, L.T. \& Ganster, D.C., 1995, 'Impact offamily-supportive work variables on work-family conflict and strain: A control perspective', Journal of Applied Psychology 80(1), 6-15. https://doi.org/10.1037/0021-9010.80.1.6

Walls, M. and E. Safirova, 2004. "A Review of the Literature on Telecommuting and Its Implications for Vehicle Travel and Emissions". Discussion Papers DP-04-44, Resources for the Future. 